REVISTA DE DERECHO UNED, NÚM. 11, 2012

\title{
REFLEXIONES Y PROPUESTAS A PROPÓSITO DE LA FUTURA LEY DE JURISDICCIÓN VOLUNTARIA*
}

\author{
REFLECTIONS AND PROPOSED BY THE WAY OF THE FUTURE \\ LAW OF VOLUNTARY JURISDICTION
}

\begin{abstract}
ANTONIO FERnÁNDEZ DE BuJÁN
Catedrático de la Universidad Autónoma de MADRID. Vocal de las Ponencias de Reforma de la Jurisdicción voluntaria 2002-2005 y 2012.

Comisión general de codificación antonio.bujan@uam.es
\end{abstract}

Resumen: Es hora ya de que la Jurisdicción Voluntaria deje de ser un campo de experimentación del legislador. Estamos ante la oportunidad de modernizar la Justicia en esta materia y de hacerlo con voluntad de permanencia en el tiempo, desde una posición de consenso y de progreso, en una esfera del Ordenamiento de marcado carácter técnico-jurídico.

Palabras clave: Jurisdicción Voluntaria; autoridad jurisdiccional; Secretario del tribunal; Notario; Registrador.

Abstract: It is time that Voluntary Jurisdiction ceases to be a mere area of experimentation for the legislator. We now have the opportunity to modernize Justice in this subject and to do so with the will of assuring its permanence in the future, from a position of consensus and progress and in a decidedly technical sphere of the Jurisdictional Order.

* El texto del presente estudio fue objeto, con mínimas modificaciones, de exposición en una Conferencia que bajo el título "La hora de la Jurisdicción Voluntaria», fue pronunciada por el Autor en el Colegio Notarial de Cataluña, en su sede de Barcelona, el día 22 de febrero del año 2012 y ha visto la luz en la Revista Jurídica del Notariado, julio-septiembre 2011, n. 79, pp. 177- 226. 
Keywords: Voluntary Jurisdiction; Jurisdictional authority; Clerk of the court; Notary; Registry

Recepción original: 10/07/2012

Aceptación original: 16/10/2012

Sumario: I. Reforma legislativa pendiente: Libro III LEC 1881. Procedimientos Específicos. Iter Legislativo de la tramitación parlamentaria; II. El nuevo perfil de la institución; II.1. Concepto y Evolución Histórica; II.2. Contenido; II.3. Garantías del procedimiento judicial de JV; II.4. Sanción constitucional; III. Racionalizar. Desjudicializar. Redistribuir. Desregular; IV. Algunas Propuestas de modificación respecto del texto normativo de JV aprobado en la Comisión de Justicia del Congreso de los Diputados; V. El papel histórico del Notariado en la JV; VI. Especial referencia a las competencias susceptibles de ser atribuidas al Notariado; VII. A modo de conclusión,

I. REFORMA LEGISLATIVA PENDIENTE: LIBRO III LEC 1881. PROCEDIMIENTOS ESPECÍFICOS. ITER LEGISLATIVO DE LA TRAMITACIÓN PARLAMENTARIA

En el marco del Estado Constitucional de Derecho, una de las piezas que todavía queda por encajar en el organigrama de la Administración de Justicia, es la correspondiente a la Jurisdicción voluntaria. La Ley de Enjuiciamiento Civil de 7 de enero del 2000, LEC, por la que se rige la jurisdicción contenciosa en los procesos civiles, establece en su Disposición Final decimoctava que: «En el plazo de un año, a contar de la fecha de entrada en vigor de esta Ley, el Gobierno remitirá a las Cortes Generales un proyecto de Ley sobre jurisdicción voluntaria».

La reforma de la jurisdicción voluntaria, JV en adelante, fue asimismo prevista en el Pacto de Estado sobre la Justicia, firmado por los dos partidos mayoritarios, el 28 de mayo del año 2001.

Por otra parte, en la afortunada y precisa Exposición de Motivos de la LEC se afirma, en el apartado quinto, que en cuanto a su contenido general, dicha ley «se configura con exclusión de la materia relativa a la jurisdicción voluntaria que, como en otros países, parece preferible regular en ley distinta». Especial significación tiene en este campo la Ley de Jurisdicción Voluntaria alemana (Freiwllige Gerichtsbarkeit) de 1898 que, con más de treinta reformas parciales, continúa en vigor. 
Un primer paso importante en el cumplimiento del mandato legislativo pendiente de cumplimiento, tuvo lugar en diciembre del año 2002, al ponerse en marcha la maquinaria legislativa con la constitución, en el seno de la Sección Segunda de la Comisión General de Codificación, máximo órgano asesor del Ministerio de Justicia en las tareas prelegislativas, de una Ponencia, presidida por el notario José María de Prada y compuesta por siete miembros, un Magistrado, un Registrador Mercantil, un Secretario Judicial, un Decano de Colegio de Abogados, y dos Catedráticos, que a lo largo de casi tres años de trabajo, elabora una propuesta normativa integrada por 306 artículos y 10 disposiciones complementarias -valoradas y tenidas muy en cuenta las observaciones formuladas por las Secciones de Derecho Civil y de Derecho Mercantil de la Comisión de Codificación- que asumida como Propuesta de Anteproyecto por el Ministerio de Justicia, es publicada en su Boletín Informativo en octubre del año 2005 «como texto preliminar de una nueva regulación de la jurisdicción voluntaria, sin duda necesaria, por lo que se hace pública por su evidente interés para la comunidad jurídica, al objeto de propiciar su conocimiento y libre discusión», según se subraya en la Nota que antecede a la Memoria Explicativa y a la Exposición de Motivos.

La ponderada propuesta de Anteproyecto elaborada por la Comisión General de Codificación gozó, de forma manifiesta, de una positiva acogida en la comunidad científica y por parte de los operadores jurídicos afectados, Jueces, Secretarios Judiciales, Notarios, Registradores, Abogados y Procuradores de los Tribunales.

A partir de este primer paso relevante del prelegislador, la propuesta de Anteproyecto de la Ponencia fue sometida a una revisión interna en el Ministerio de Justicia, fruto de la cual fue el Anteproyecto de Ley de Jurisdicción Voluntaria, aprobado en Consejo de Ministros de 2 de junio de 2006. Finalmente, el veinte de octubre del año 2006, el Consejo de Ministros aprobó la remisión a las Cortes Generales del Proyecto de Ley de Jurisdicción Voluntaria, para facilitar y agilizar la tutela y garantía de los derechos de la persona, en materia civil y mercantil, que reprodujo, con escasas modificaciones, el texto del Anteproyecto de Ley de junio de 2006, y si bien introdujo mejoras en determinados aspectos contemplados en el Anteproyecto de la Ponencia, cambió la concepción de la JV, al administrativizar el procedimiento judicial en la terminología y en el contenido y establecer una artificiosa equiparación, entre procedimientos de diferente naturaleza, como son el judicial y el administrativo notarial y registral, lo que se materializó en la supresión de la contradicción, de los recursos y de la asistencia técnica en los procedimientos de JV judiciales. 
La desacertada, a mi juicio, previsión, que implicaba un estéril reduccionismo de la $\mathrm{JV}$ al ámbito negocial y administrativo, fue por fortuna corregida en trámite de enmiendas en la Comisión de Justicia del Congreso de los Diputados, que procedió a la recuperación de las connotaciones jurisdiccionales del procedimiento judicial de JV, y a una distinta regulación de los procedimientos judicial y administrativo de JV, en atención a su diferente naturaleza jurídica, y a las reglas de funcionamiento y principios informadores propios de su conformación en el Ordenamiento Jurídico. En trámite de enmiendas se presentaron un total de 323 al articulado del Proyecto.

El 27 de junio de 2007, fue aprobado en la Comisión de Justicia del Congreso de los Diputados, con Competencia Legislativa Plena, el Proyecto de Ley de Jurisdicción Voluntaria, antes denominado Proyecto de Ley de jurisdicción voluntaria para facilitar y agilizar la tutela y garantía de los derechos de la persona en materia civil y mercantil, con un contenido de 229 artículos y 17 disposiciones complementarias, el 24 de julio, el texto legislativo, entró en el Senado, en cuya Comisión de Justicia los distintos Grupos Parlamentarios presentaron y debatieron un total de 239 enmiendas. En trámite de asesoramiento, tuvo asimismo lugar la comparecencia, ante la Comisión de Justicia del Congreso de los Diputados, de 14 expertos en la materia de JV, entre los que tuve el honor de representar a la Comisión General de Codificación. Finalmente, el 24 de octubre de 2007, el Gobierno procedió a retirar el Proyecto, el día en que iba a ser votado en el Pleno del Senado.

Desde entonces hasta hoy la proyectada y, con posterioridad, frustrada reforma de la JV no ha tenido una existencia airosa, al quedar relegada en el ostracismo de los buenos deseos que no llegan a materializarse. Es por ello que los juristas y los conocedores de la relevancia que supone una nueva regulación de la JV, hemos saludado con satisfacción que en el Discurso de Investidura del pasado 19 de diciembre de 2011, Mariano Rajoy expresase, como futuro Presidente del Gobierno español, que constituía una de sus prioridades, en el ámbito legislativo, su voluntad de aprobar, en la presente Legislatura, la Ley de Jurisdicción Voluntaria. En el mismo sentido, se pronunciaba, pocos días después, Alberto Ruiz Gallardón, en su toma de posesión como Ministro de Justicia, y en sus comparecencias en la Comisión de Justicia del Congreso de los Diputados y en el Senado, ésta última el pasado día 5 de marzo de 2012.

En tanto no se apruebe una Ley de Jurisdicción Voluntaria, continúa vigente, con determinadas excepciones, conforme se establece en la disposición derogatoria única, apartados 1 y 2 de la nueva LEC, 
la regulación contenida en el libro III de la LEC 1881, relativa a la Jurisdicción Voluntaria, así como la correspondiente a la conciliación y a la declaración de herederos abintestato.

En contraposición, sin embargo, con la mencionada previsión legal, con la conciliación ha pasado lo que sucedió con las diligencias preliminares, que siendo ambas instituciones propias de la jurisdicción voluntaria han sido reguladas en sedes de naturaleza heterogenea. Así, la conciliación en la reciente Ley de Reforma de la legislación procesal para la implantación de la Nueva Oficina Judicial del año 2009, y las diligencias preliminares en la propia Ley de Enjuiciamiento Civil, reguladora de la jurisdicción contenciosa ${ }^{1}$.

Conviene señalar, por otra parte, que si bien un amplio número de los supuestos de jurisdicción voluntaria judicial se contienen en el libro III de la LEC, otros muchos en los que está prevista la intervención del juez o se incluyen en el marco de la denominada jurisdicción voluntaria notarial o registral, se regulan en textos legislativos diversos, como el Código Civil, el Código de Comercio, la Legislación hipotecaria, o la Ley y el Reglamento del Registro Civil.

En los últimos años, se ha generado, en un marco de expansión de la institución, una inflación de procedimientos específicos, sin que exista proceso, contemplados en leyes civiles o mercantiles, que no siempre resultan justificados en su especificidad, pero que en buena medida se amparan en la ausencia de un procedimiento global de jurisdicción voluntaria en el libro III de la LEC. Cabría citar, entre otros textos, en los que se regulan actos de jurisdicción voluntaria, las siguientes disposiciones legislativas: ley 30/1979, de 27 de diciembre, en materia de trasplantes de órganos; Ley 50/1980, de 8 de octubre, sobre Contrato de seguro, a propósito de nombramiento de tercer perito; ley 11/1981, de 13 de mayo, en materia de filiación, patria potestad y régimen económico del matrimonio; Ley 30/1981, de 7 de julio, sobre nulidad, separación y divorcio; Ley 1/1982, de 5 de mayo sobre derecho al honor, intimidad personal y familiar y propia imagen, en relación con los menores; ley 13/1983, de 24 de octubre, sobre tutela y curatela; Ley 19/1985, de 16 de julio, Cambiaria y del Cheque; Ley

${ }^{1}$ En este sentido en Díez-Picazo, I., Derecho Procesal Civil. El proceso de declaración, Madrid, 2001, pp. 229: «...aunque la doctrina considera las diligencias preliminares actuaciones de jurisdicción voluntaria, y la jurisdicción voluntaria ha quedado fuera del ámbito objetivo de la LEC, en este caso el legislador ha hecho una excepción a esa regla. Probablemente la razón de que la LEC, regule las diligencias preliminares pese a ser actos de jurisdicción voluntaria debe buscarse en la necesidad que había de introducir cambios en su regulación para darles mayor eficacia, lo que no debía esperar hasta la aprobación de la futura Ley de Jurisdicción Voluntaria». 
Foral de Navarra 5/1987, de 1 de abril, sobre autorización judicial para enajenar o gravar bienes fideicomisarios; Ley 21/1987, de 11 de noviembre, en materia de acogimiento y adopción; Ley 22/1987, de 11 de noviembre, en materia de Propiedad Intelectual, en supuestos de discrepancias sobre remuneración equitativa del autor, divulgación de la obra, subsanación de omisiones, reanudación de explotación de obra etc., que requieran autorización judicial; Ley de la Generalitat de Cataluña, 40/1991, de 30 de diciembre, reguladora del Código de Sucesiones por causa de muerte, sobre autorización judicial en materia de conmutación o conversión del modo que grava una institución de heredero o de legado; Ley 1/1996, de 15 de enero, de Protección Jurídica del menor; Ley de la Generalitat de Cataluña 9/1998, de 15 de julio, reguladora del Código de Familia, en materia de idoneidad para la adopción; Ley de la Generalitat de Cataluña, 18/2002, de 5 de julio, en materia de cooperativas, Ley 9/2000, de 10 de diciembre, sobre sustracción de menores, Ley 41/2003, de 18 de noviembre, sobre Protección patrimonial de las personas con discapacidad, etc...

El título competencial de la futura LJV es el artículo 149.1.6 de la C.E., que atribuye al Estado la regulación de la legislación procesal, excepto alguna disposiciones concretas que se dictan al amparo de la competencia que corresponde al Estado en materia de legislación civil, mercantil, y de ordenación de los registros e instrumentos públicos, conforme al artículo 149.1.6 y $8 \mathrm{CE}$, sin perjuicio de las necesarias especialidades que en este orden se deriven de las particularidades del derecho sustantivo de las Comunidades Autónomas. En este sentido cabe mencionar la intervención del portavoz de CIU, Jordi Jane, quien afirmó en el curso del debate parlamentario que: «... la LJV que se apruebe debe estar claramente ajustada al marco estatutario, por tanto al Estatut de Cataluña, que es tanto como decir al marco constitucional, dado que los estatutos forman parte del bloque de constitucionalidad. Así el art. 147 del Estatut de Autonomía de Cataluña da competencia ejecutiva a la Generalitat en el establecimiento de las demarcaciones notariales y registrales».

\section{EL NUEVO PERFIL DE LA INSTITUCIÓN}

\section{II.1. Concepto y Evolución Histórica}

La Jurisdicción Voluntaria, JV en adelante, ha sido descrita o calificada por la doctrina y la jurisprudencia con los más variados epítetos: misteriosa, heterogénea, fascinante, atormentada, insisten- 
te, machacona y dando respuesta a problemas concretos, repudiada por todos y sin sede científica propia, enojosa, difícil y de poco lucimiento, uno de los más atormentados problemas de la ciencia jurídica europea, la gran olvidada y por qué no decirlo, la gran ignorada, inquisitiva o paradigmática por su brevedad y economía procesal pero, en la práctica, salvo valiosas excepciones, singularmente González Poveda, Ramos Méndez y Almagro Nosete, ha suscitado escaso interés en la doctrina científica, y en el desarrollo argumental de la doctrina jurisprudencial, si nos atenemos a la relevancia de la parcela imprescindible de la realidad social que constituye su campo de aplicación ${ }^{2}$, si bien ha de subrayarse que, en el último decenio, la

${ }^{2}$ En análogo sentido, se manifiesta MuÑoz RoJAs, Sobre la jurisdicción voluntaria, Actualidad Civil, 1989, num. 39/90, pp. 577-585, cuando afirma que: «en el ámbito jurídico, es tan necesaria la jurisdicción voluntaria como la jurisdicción contenciosa: cada una de ellas tiene su respectivo campo de aplicación y no son intercambiables. Si está justificada en nuestro Ordenamiento la reforma de las leyes procesales, la misma o mayor justificación tiene la depuración, actualización o mejora de los expedientes de jurisdicción voluntaria adaptados a la reforma de las leyes sustantivas, sin perjuicio de la ley básica de dichos procedimientos». Especial relevancia en la doctrina española en la materia tienen las obras de Ramos Méndez, La jurisdicción Voluntaria en Negocios de Comercio, Madrid 1978; Almagro, en Derecho Procesal Civil, T. I, Vol. II, Valencia 1992; y Gónzalez Poveda, La Jurisdicción Voluntaria, Pamplona, 3. a ed. 1997.

En el último decenio, la previsión legislativa referida a la jurisdicción voluntaria ha estimulado la producción doctrinal. Vid. al respecto, entre otros estudios, en Fernández de Buján, A., Jurisdicción voluntaria. Madrid, 2001; Id. Hacia una Teoría General de La Jurisdicción Voluntaria I, Iustel, Madrid 2007; Id. Hacia una Teoría General de la Jurisdicción Voluntaria II, Iustel, Madrid 2008; Id. La Jurisdicción Voluntaria, Madrid, 2001; Id., "La reforma de la Jurisdicción Voluntaria: problemas, interrogantes, soluciones», Diario LA LEY, 23 de marzo de 2005; Id., «El nuevo perfil de la Jurisdicción Voluntaria en el Anteproyecto de Ley de octubre de 2005. De la tutela de relaciones jurídico privadas a la protección de intereses generales, públicos o sociales», Diario LA LEY, 8 de junio de 2006 Id., «Observaciones al proyecto de ley de Octubre de 2006 (I)»,Diario LA LEY,27 de noviembre de 2006;Id. "Observaciones al proyecto de ley de Octubre de 2006(II)», Diario LA LEY,28 de noviembre de 2006; $I d$., "La Jurisdicción Voluntaria. El Anteproyecto de junio de 2006», en El Notario del siglo XXI, agosto de 2006; Id. El fracaso de la Jurisdicción Voluntaria. Registradores, enero-febrero 2008; Id. Comparecencia ante la Comisión de Justicia del Congreso de los Diputados en trámite de asesoramiento, Diario de Sesiones. Congreso de los Diputados, n. 821, de 7 de mayo de 2007; Id. La Jurisdicción Voluntaria en el marco del Estado constitucional de Derecho, Anales de la Academia Matritense del Notariado, 2007, Id. La Oficina Judicial y la Jurisdicción Voluntaria: dos reformas procesales a debate en el panorama legislativo español, Estudios en Homenaje al Profesor Elías Díaz, RJUAM, Revista Jurídica de la UAM, 2009, y en: Publicaciones de la Real Academia de Jurisprudencia y Legislación: Problemas actuales de la Jurisdicción, 2010, T.II, pp. 1462-1477. Id. El necesario debate sobre el nuevo modelo de Oficina Judicial, Número especial de La Ley sobre la Oficina Judicial. N. 7.191, de 8 de junio de 2009, pp. 8-11; Id. Jurisdicción Voluntaria: aprender de los errores del pasado, Revista: El Notario del siglo XXI, Núm. volumen: 31,2010, pp. 66-74; Id. Xurisdicción voluntaria: 
previsión legislativa referida a la jurisdicción voluntaria ha estimulado la producción doctrinal.

Frente a posiciones maximalistas del tipo «la jurisdicción voluntaria podría ser eliminada de cualquier Ordenamiento Jurídico» o la de «las necesidades negociales y el tráfico jurídico, justifican la aplicación del procedimiento voluntario a supuestos de lesión de derechos o intereses legítimos», se impone una posición realista, en la que se sitúan las más modernas corrientes de la ciencia procesal, partidarias de regular, sin quiebra de las garantías esenciales del proceso, y sin desnaturalizar el marco que le es propio, una parcela imprescindible de la realidad social, en constante expansión, fruto del nuevo perfil de la jurisdicción voluntaria, que ha evolucionado desde la originaria tutela de relaciones jurídico privadas, a la actual protección de derechos indisponibles, intereses generales, públicos o sociales, así como a la resolución de conflictos de intereses considerados de relevancia menor.

No debería, finalmente, extenderse artificiosamente el campo de la jurisdicción voluntaria fuera de su propio ámbito, por meras razones de economía procesal, lo que se produciría si se tramitasen por la vía del procedimiento voluntario supuestos de tutela de derechos o intereses lesionados o supuestos de conflicto relevante. No se puede establecer una jurisdicción voluntaria contra natura por un simple deseo de celeridad. Una cosa es que se facilite la transacción,

una reforma lexislativa pendente para a nova lexislatura, n. 41, Revista Galega de Administración Pública, enero-junio 2011, pp. 11-46; Id. Convención de 2006 sobre los derechos de las persona con discapacidad y proceso de incapacitación: Revista ICADE. Universidad Pontificia Comillas, septiembre-diciembre 2011, pp. 119-155; Id. La Jurisdicción Voluntaria en el Plató. El Notario del siglo XXI, n. 41, enero-febrero 2012, pp. 22-33; Id. Capacidad, discapacidad, incapacidad, incapacitación, en Revista de Derecho Uned, n.9 2012, pp. 83-92; Id. Incapacitación y Discapacidad. Tratado de Derecho de Familia. Coordinado por Gema Díez-Picazo. Capítulo VII. ThompsonAranzadi, 2012, pp. 1903-1954; Rodriguez Adrados, El anteproyecto de ley de jurisdicción voluntaria, Anales de la Real Academia de Jurisprudencia y Legislación, Madrid 2006; De Prada González, «En torno a la futura ley de Jurisdicción Voluntaria», en El Notario del siglo XXI, diciembre 2005; Id. Por qué ha fracasado el Proyecto de Ley de jurisdicción Voluntaria, El Notario del siglo XXI, 16.2007, pp. 70 ss; Ramos Méndez, "¿Cuánta dosis de jurisdicción voluntaria necesitamos?», Justicia 2006; Rodriguez Adrados, «El anteproyecto de ley de jurisdicción voluntaria», ANALES Real Academia de Jurisprudencia y legislación, Madrid 2006; Seoane Cacharrón, «Breve examen crítico del Anteproyecto de Ley de Jurisdicción Voluntaria del Ministerio de Justicia de 1 de junio de 2006», Diario La Ley, 28 de septiembre de 2006; Id, "El Secretario Judicial como órgano de la Jurisdicción Voluntaria en el proyecto de ley de 27 de Octubre de 2006», Diario LA LEY, 15 de Mayo de 2007; Id, "Examen del procedimiento Judicial común en el Proyecto de Ley de Jurisdicción Voluntaria», Diario LA LEY, 6 de Septiembre de 2007. 
y el compromiso, y otra es que se desnaturalice en un procedimiento voluntario, el conocimiento de supuestos en los que lo que subyace es la tradicional lucha por el derecho.

Sería deseable, en todo caso que, se valorase la creación, en el futuro, de juzgados que tuviesen atribuida la competencia en exclusiva en esta materia, tal como sucedía en la Edad Media, con los iudices chartularii, que pertenecían normalmente a la profesión notarial, ante los que, en atención a su especialización judicial, se desarrollaba, con carácter exclusivo, la ficción procesal que encubría el negocio de jurisdicción voluntaria. En los pasados decenios, en torno a un $10 \%$ de los asuntos conocidos en los juzgados civiles se corresponden con procedimientos de jurisdicción voluntaria.

No es la jurisdicción voluntaria, por otra parte, una simple expresión nominal que, utilizada por el legislador como campo de experimentación o mero catalizador de procedimientos heterogéneos, carezca de justificación racional, ni de fundamentación histórica. Muy por el contrario, ya en Derecho Romano, existió el sustrato social y la realidad jurídica, de lo que por primera vez, en la historia de la ciencia jurídica europea, un jurista romano, del siglo III d.C., llamado Marciano, en su obra Instituciones, con posterioridad recogida en el Digesto de Justiniano, denomina jurisdicción voluntaria, «iurisdictio voluntaria». "Todos los procónsules, una vez que salen de la ciudad, tienen jurisidicción, pero no contenciosa sino voluntaria, por ej pueden autorizar manumisiones, emancipaciones y adopciones», si bien la realidad jurídica que se engloba en la expresión JV se remonta a los primeros siglos de la experiencia jurídica romana, así a tres supuestos paradigmáticos de JV, el nombramiento de tutor de los menores no sometidos a patria potestas y de curador en los casos de personas con enfermedad mental aguda y de prodigalidad, se hace ya mención en el Código de las XII Tablas del siglo V a C.

La JV era entonces, en Derecho Romano, pacifica, negocial y voluntaria, y de ahí la denominación de Marciano, en la medida en la que las partes acudían de común acuerdo ante el Magistrado y fingían la existencia de un conflicto, que de inmediato se diluía ante el allanamiento que una de las partes realizaba ante la afirmación de la otra, y por medio de esta fórmula procesal se hacía efectiva la transmisión de un derecho de servidumbre, de usufructo, la posición de heredero, un derecho de alimentos entre parientes etc.

Cuando escribe Marciano el texto de referencia ha desaparecido ya la ficción procesal, que reaparece siglos después en la Edad Media, y lo que hace el magistrado es un control de legalidad de la 
solicitud del promovente o del acuerdo inter partes, y verificado éste, procede a autorizar, habilitar, constituir o declarar la existencia de un derecho, en una etapa en la que el ejercicio de la jurisdicción es ya un oficio de un contenido amplísimo, que no sólo se identifica con el proceso, como así fue durante siglos, sino que comprende cualquier acto o poder del Magistrado jurisdiccional, conforme parece derivarse de un texto de Ulpiano, contenido en D. 2.1.1: «El oficio del magistrado es amplísimo, ius dicentis officium latissimum est, así pues, puede proceder al nombramiento de tutor a quien carece de él, poner en posesión de los bienes hereditarios a quien los haya recibido por herencia, ordenar la entrega en posesión de bienes o nombrar jueces a los litigantes».

Asimiladas en la época clásica romana a la jurisdicción voluntaria determinadas actuaciones formalizadas ante los funcionarios encargados de los Archivos o Registros Públicos y ante los Notarios o Tabeliones, es en la Edad Media cuando se atribuye ya a los Notarios competencias específicas en materia de jurisdicción voluntaria, primero como profesionales adscritos a los tribunales, civiles y eclesiásticos y, con posterioridad, como ya ha sido subrayado, como titulares de los juzgados, iudices chartularii, con competencia específica para conocer de los asuntos de jurisdicción voluntaria, ante los que se desarrollaba la ficción procesal que encubría el negocio de jurisdicción voluntaria, en una primera etapa, superada la cual, se procedía a la formalización del procedimiento de jurisdicción voluntaria, tramitado fuera ya del marco del proceso contencioso.

La expresión JV se trasmite en la Edad Media, a través de los glosadores y comentaristas al Derecho Común, y de éste pasa a los códigos modernos y a las legislaciones de los distintos países europeos.

La denominación de Jurisdicción Voluntaria tiene, por tanto, una fundamentación histórica derivada de su utilización sin intervalos durante casi veinte siglos, y la reforma de la Justicia no debe ni puede prescindir de la historia, en afortunada expresión de la EM de la LEC, a lo que ha de añadirse el valor derivado del arraigo de una terminología utilizada de forma usual en el lenguaje común, en el de los operadores jurídicos y en la tradición jurisprudencial, así como la inutilidad de los esfuerzos doctrinales y legales realizados en otras latitudes para encontrar una expresión comprensiva del fenómeno que nos ocupa.

Así, denominaciones como proceso no contencioso o procedimiento en Cámara de Consejo se han revelado como insatisfactorias, y no han logrado sustituir en los propios países en que se han 
introducido a la denominación clásica que ha seguido presente en las aportaciones científicas y, en ocasiones, de forma casi freudiana, en el propio texto de la ley ${ }^{3}$. Jurisdicción contenciosa y voluntaria, una vez desgajadas de ésta las artificiosas adherencias que no le son propias, constituyen esferas de la jurisdicción, que requieren una actividad de enjuiciamiento del órgano jurisdiccional, si bien en la jurisdicción voluntaria judicial que se enmarca, en gran parte de su contenido, en el amplio campo del ejercicio pacífico de los derechos, y de ahí la justificación funcional de la denominación, no existen, en general, posiciones contrapuestas, a priori, de personas enfrentadas, salvo supuestos de conflictos de relevancia menor, mientras que en la jurisdicción contenciosa, lo normal es la existencia de una controversia entre los litigantes, aunque hay también procesos declarativos o constitutivos en los que no existe oposición. Se trata, en estos casos, de auténticos procesos sin contradicción de voluntades como, por ejemplo, sucede en los supuestos de las denominadas sentencias sin oposición.

\section{II.2. Contenido}

Con la expresión jurisdicción voluntaria, en sentido estricto, se hace referencia a aquellos procedimientos en los que un particular solicita la intervención de un juez, o éste interviene de oficio o a instancia del Ministerio Fiscal sin que exista una contienda relevante con otra persona, o una lesión de derecho subjetivo o interés legítimo.

Son, por ejemplo, supuestos de jurisdicción voluntaria -de entre los más de 200 pendientes de nueva regulación, racionalización y redistribución- la adopción de medidas relativas al traslado o retención ilícita de menores en actuaciones de sustracción internacional, es decir, el conocido como secuestro parental, la aprobación

${ }^{3}$ Art. 32, disp. Att. del Código Civil Italiano: «el ministerio público debe ser oído siempre en los procedimientos de jurisdicción voluntaria que tienen contenido patrimonial»; arts. 35 y 36 del D.P.R., 5 de enero de 1967, n. 200, que regulan las funciones y competencias de los cónsules en materia de jurisdicción voluntaria; arts. 9 , 66 y 67 de la reciente ley de 31 de mayo de 1995, reformadora del sistema italiano de derecho internacional privado, mediante los que se regulan las hipótesis en que subsiste la jurisdicción del juez italiano en materia de jurisdicción voluntaria, así como los presupuestos y la eficacia en Italia de los procedimientos de jurisdicción voluntaria en los que intervienen jueces extranjeros. Vid. al respecto en VENTURINI, Consideración sulla qualificazione dei procedimenti stranieri di giuridiszioni volontaria, Rivista di Diritto Internazionale privato e procésale, 2003, pp. 813-910. En relación con el estudio histórico de la institución de la jurisdicción voluntaria vid., FERNÁNDEZ DE Bujan, A., Jurisdicción voluntaria en Derecho Romano, Madrid, 3. a ed. 1999. 
del reconocimiento de la filiación extramatrimonial; la protección patrimonial de las personas con discapacidad; la declaración de ausencia o fallecimiento de una persona; que se proceda al nombramiento de un tutor o que se autorice a éste la venta de un inmueble de su pupilo; la constitución de una adopción o de un acogimiento familiar; las autorizaciones relacionadas con el honor, la intimidad o la propia imagen del menor; la autorización para el trasplante de órganos de personas fallecidas; que se autorice la convocatoria de una junta general ordinaria de sociedad anónima que no se hubiese convocado en el plazo legal; que se acuerden medidas de garantía en relación con la mala administración de los padres; que se disponga el depósito y venta de mercancías y equipajes en los casos en que el destinatario no abone el flete o el pasaje; la auditoría de las cuentas de los empresarios; el nombramiento de perito en el seguro de daños; que se autorice al capitán del buque, la venta de un cargamento, en peligro de avería, en el puerto de arribada y no en el de destino; la liquidación y distribución de una avería gruesa, en materia de derecho marítimo, o los supuestos de intervención judicial, sin que exista proceso, en relación con la restricción de derechos fundamentales.

Se incluyen asimismo dentro de la esfera de la jurisdicción voluntaria un conjunto de procedimientos dirigidos a la solución judicial de conflictos que el ordenamiento jurídico considera que no tienen entidad suficiente para ser dirimidos en un proceso contencioso, entre los que cabe señalar las controversias entre los progenitores en el ejercicio de la patria potestad, o los desacuerdos entre los esposos en la gestión de los bienes comunes. Se trataría de supuestos en los que la urgencia o la conveniencia de eludir la excesiva dilación del juicio ordinario, justificaría la tutela simplificada, ágil y flexible del procedimiento voluntario, que cumpliría, en estos casos, el papel que correspondería a un especial procedimiento sumario contradictorio.

Son considerados finalmente procedimientos de jurisdicción voluntaria judicial otros supuestos en los que la intervención del juez queda reducida a la mera presencia, comprobación de hechos, calificación, autentificación o documentación del acto o relación jurídica, lo que supone una desnaturalización de lo que debe entenderse por potestad jurisdiccional, ni parece asimismo necesaria en éstos supuestos la actuación judicial en garantía de derechos, que con carácter compartido con otros poderes del Estado, se atribuye a los jueces y tribunales en el artículo 117.4 de la Constitución.

Sería pues deseable, en este ámbito de reflexión, y en atención a las enseñanzas de la experiencia histórica, la dogmática jurídica y la 
realidad social propia de esta esfera del Ordenamiento, deslindar entre aquellas competencias que deben continuar atribuidas al órgano jurisdiccional, por razón de su naturaleza jurídica, o bien debido a la consideración de los jueces como los operadores jurídicos que gozan de un mayor grado de independencia e imparcialidad en el ejercicio de su función, y aquellas otras competencias que, atribuidas en su momento -finales del siglo XIX- a los jueces, en atención a su prestigio, a la seguridad jurídica que producía su intervención, a la prevención o desconfianza frente a otros operadores jurídicos, o a razones de mera tradición historicista, oportunidad, conveniencia o división del trabajo, podrían desjudicializarse, al desparecer las razones de política legislativa que constituían su fundamento, y atribuirse, en la parte correspondiente a disposiciones finales, a profesionales del derecho, Notarios y Registradores de la Propiedad y Mercantiles, a quienes corresponden con mayor propiedad el ejercicio de estas funciones, en atención a su propia naturaleza así como a su especialización y cualificación jurídicas. Se trataría con ello no tanto de evitar el colapso de la justicia contenciosa, sino sobre todo de sistematizar y redistribuir funciones, en aras de la racionalización del sistema y como demostración de confianza en la madurez de la sociedad civil.

La intervención de oficio del juez y del fiscal está prevista en supuestos de procedimientos de jurisdicción voluntaria que afectan a menores, incapacitados o desvalidos, en estrecha relación con los preceptos constitucionales (arts. 9.2 y 53.3 CE) referidos al Estado social, o bien a la condición y estado civil de las personas, o a intereses jurídico-públicos, generales o sociales

\section{II.3. Garantías del procedimiento judicial de JV}

La previsible futura concepción de la JV judicial debe caracterizarse por su sustancial aproximación a la jurisdicción contenciosa, en materia de garantías del procedimiento. La previsión legal contenida en el artículo 22 del Proyecto de Ley de 2006 conforme a la cual: «La comparecencia se sustanciará por los trámites del juicio verbal con las siguientes especialidades», supone la supresión de las particularidades previstas en materia de JV y una práctica equiparación en la regulación de ambas esferas de la jurisdicción. Así en materias como:

- Días y horas hábiles;

- Desaparición de la posibilidad de modificar de oficio las «La providencias y autos no definitivos, conforme al 1818 
LEC, que suponía una desvirtuación de lo previsto en la LOPJ, arts. 18 y 267, que establecen el principio de que las resoluciones judiciales sólo quedarán sin efecto en virtud, en su caso, de los recursos previstos por las leyes.

- Reforzamiento del principio de igualdad de partes, en la medida en que se produce una atenuación o práctica desaparición, en algunos casos de JV, de la posición de solicitantes, interesados (es, decir personas con interés concurrente o complementario, de cualquier tipo, jurídico, económico, moral etc., con el del solicitante), contrainteresados (es decir, personas con interés divergente al expresado por el solicitante) y afectados, en relación con la audiencia, alegaciones, testimonios (por ej. de terceros no interesados a las que el procedimiento no afecta, en sentido estricto, a sus intereses), pruebas (en contraposición a las actuales informaciones, acreditaciones y justificaciones), trámite de conclusiones, registro de la comparecencia en soporte apto para la reproducción del sonido y la imagen, plazo para subsanar los posibles defectos u omisiones en las solicitudes, asistencia técnica, justicia gratuita, recursos etc., así como en aquellos supuestos en que por análogas motivaciones, rige el principio de impulso de oficio en el proceso contencioso o en el procedimiento de JV.

- Previsión de la controversia y la oposición.

- Plazos cortos y prorrogables. Asunción, con carácter general, del principio preclusivo.

- Previsión se subsanación de posibles defectos u omisiones en las solicitudes, conforme al art. 23.1 del Proyecto de Ley de JV de 2006.

- Supresión del régimen singular de la apelación en uno o dos efectos, ex arts. 1819 y 1820. Previsión de supletoriedad de la Ley Procesal Civil, conforme al art. 12 del Proyecto: «La Ley de Enjuiciamiento Civil será de aplicación supletoria a los expedientes de Jurisdicción Voluntaria administrados por Jueces y Secretarios Judiciales en lo no previsto por esta Ley».

Resultaría apropiado, asimismo, un reforzamiento de los principios dispositivo y de aportación de parte en el procedimiento voluntario, una atenuación del dirigismo judicial, que en consonancia con la libertad de forma y el carácter más potestativo de la actuación judicial en esta esfera de la jurisdicción, pueda poner en riesgo las fundamentales garantías inherentes a todo procedimiento, una li- 
mitación del principio de impulso de oficio a aquellos supuestos de derechos indisponibles o de interés general, públicos o sociales y una aproximación de las posiciones de solicitante, interesados y terceros, en especial en aquellos supuestos en los que el interesado exprese un interés contrario al manifestado por el promovente, es decir, en aquellos casos en que nos encontremos en presencia de lo que se denomina contrainteresado en la legislación italiana, no obstante lo cual, no se produce un sobreseimiento del expediente.

El carácter variable y fluido entre jurisdicción contenciosa y jurisdicción voluntaria, en atención a las decisiones contingentes de política legislativa ha sido por otra parte, una constante en la historia de ambas esferas de la jurisdicción, y así por ejemplo los alimentos provisionales y la incapacitación por locura, fueron en una primera época de vigencia de la LEC 1881 expedientes de jurisdicción voluntaria, siendo con posterioridad transvasados a la jurisdicción contenciosa. En la misma línea, el legislador de la Ley Procesal Civil del año 2000 ha incluido en su seno supuestos que con anterioridad se regulaban por el trámite voluntario, como el internamiento de personas incapaces por trastornos psíquicos o conforme al artículo 770 LEC, las pretensiones que se formulan al amparo del título IV, libro I del Código Civil, relativo al matrimonio, que se sustancian por los trámites del juicio verbal.

A la necesidad de regular la contradicción en el procedimiento de JV judicial, que constituía, a mi juicio, la deficiencia de mayor calado del texto legislativo presentado en el año 2006, se refirieron todos los expertos que comparecieron en la Comisión de Justicia del Congreso de los Diputados, los días 7 y 14 de mayo de 2007, a fin de asesorar sobre el contenido del Proyecto.

Carece de sentido articular un procedimiento judicial garantista, como en efecto así se había hecho, en contraposición a la vigente previsión legal que adolece de esta nota caracterizadora, entre otros aspectos, en materia probatoria y de audiencia, y aplicarlo tan sólo a menores e incapaces, como se preveía en el Proyecto del Gobierno de 2006. Resultaba asimismo artificioso optar por una concepción de la JV basada únicamente en la ausencia de conflictividad como elemento diferenciador con la jurisdicción contenciosa, conforme a un modelo ya superado en la vigente legislación sustantiva y procedimental, española y comunitaria, como así fue subrayado en los preceptivos dictámenes del Consejo General del Poder Judicial y del Consejo Fiscal. 
Lógicamente si se acude al órgano judicial, en numerosos supuestos de JV en los que no están afectados intereses de menores o incapacitados, es ante la falta de acuerdo entre los interesados. Así, por ejemplo, para proceder a la consignación de un objeto o de una cantidad de dinero; para fijar el plazo para el cumplimiento de una obligación; para obligar a exhibir la contabilidad de una empresa o a auditar las cuentas de un empresario; para convocar una junta o asamblea general; para nombrar un tercer perito en un contrato de seguro; para proceder a liquidar una avería gruesa, o para resolver las discrepancias surgidas en el contrato de fletamento, entre fletador, como titular de las mercancías transportadas y fletante, como porteador de éstas, por señalar sólo alguno de los muchos supuestos en los que la discordancia es manifiesta o está subyacente, es porque existe un problema sin resolver o una necesidad que atender del ciudadano que acude en ayuda del órgano judicial. En otras ocasiones, es el propio texto legal el que prevé que la oposición no hará contencioso el expediente, como así sucede en la presentación y adveración del testamento ológrafo o del testamento cerrado, o en los supuestos de extravío, sustracción o destrucción del conocimiento de embarque.

Muchos de los procedimientos de JV tienen, definitiva, controversia desde el inicio. En su intervención de 17 de mayo de 2007, en trámite de asesoramiento ante el Congreso de los Diputados, la entonces decana del I. Colegio de A. de Barcelona, se refería a esta circunstancia y ponía como ejemplo el procedimiento de restitución de menores, en los casos de secuestro del menor por alguno de los progenitores, el denominado secuestro parental, que la Ley de Protección Jurídica del Menor de 1996, obliga a tramitar en el marco de la JV. Lo ponía como ej. de JV con controversia ab initio y de supuesto que requiere la intervención preceptiva de abogado, a los efectos de que los interesados dispongan de un asesoramiento técnico cualificado en relación con la documentación a presentar, las pruebas dirigidas a fundamentar las decisiones tomadas o la petición realizada etc.

En materia de efectos de la controversia se volvió, en el curso de la tramitación parlamentaria, a la regulación prevista en el Anteproyecto de la Comisión de Codificación, lo que supone optar por hacer una Ley eficaz y que resuelva los problemas que se plantean cuando se acude a un operador jurídico para que incoe un procedimiento, dado que la opción por el archivo del expediente cuando se genere una controversia y la oposición consiguiente, traería consigo la ineficacia de la Ley y, en consecuencia, los ciudadanos dejarían de acudir a la JV. La razonable regulación de la oposición prevista en 
la Ponencia de la CGDC y asumida en el Congreso de los Diputados se contiene en el art. 7 del Anteproyecto conforme al cual:«Salvo que la ley expresamente lo prevea, la formulación de oposición por algún interesado en el asunto no hará contencioso el expediente ni impedirá la tramitación del mismo hasta su resolución, que surtirá los efectos que correspondan a tenor de su contenido en tanto no sea revocado o modificado en proceso declarativo promovido por persona legitimada». La fundamental enmienda sobre los efectos de la controversia, la n. 100, sin duda la esencial, a mi juicio, en el logro de una Ley de JV eficaz, fue presentada y defendida en la Comisión de Justicia del Congreso de los Diputados por el Grupo Parlamentario Mixto.

\section{II.4. Sanción Constitucional}

En relación con la sanción constitucional de la JV me parece plenamente acertado la argumentación contenida en el Fundamento de Derecho sexto de la STS de 22 de mayo del año 2000 (Sala de lo Contencioso-Administrativo, Sección $6{ }^{\mathrm{a}}$ ), de la que fue Ponente el Magistrado Peces Morate: «...El que se admita la existencia de actuaciones de jurisdicción voluntaria, atribuidas a órganos no judiciales, para los que tal denominación es harto discutible, no supone que cuando un juez o tribunal está llamado por Ley a definir un derecho o a velar por él, sin que exista contienda entre partes conocidas o determinadas( artículo 1811 de la vigente Ley de Enjuiciamiento Civil) su actuación no debe estar revestida de las garantías propias de la jurisdicción... No se puede afirmar que en la denominada jurisdicción voluntaria los jueces y tribunales no están ejerciendo funciones jurisdiccionales (juzgar y hacer ejecutar lo juzgado), con independencia de que ulteriormente quepa sobre lo mismo otro proceso contradictorio y, en consecuencia, esas potestades quedan amparadas por el artículo 117,3 de la Constitución, según el cual su ejercicio ha de hacerse con arreglo a las normas de competencia y procedimiento que las leyes establezcan. Las demás funciones, que el art. 117.4 CE permite que una Ley atribuya a los jueces y tribunales en garantía de cualquier derecho, son aquéllas que, a diferencia de las denominadas de jurisdicción voluntaria, no comportan protección jurisdiccional de derechos e intereses legítimos, como en los supuestos (citados por los demandados) de participación de jueces o magistrados en los Jurados de Expropiación Forzosa o en la Administración Electoral, en que aquellos se incorporan a otras Administraciones del Estado por la garantía que su presencia en ellas confiere...». 
Si analizamos la actuación del Presidente del TSJ en la tramitación y resolución de dicho recurso, se constata la existencia de los requisitos o notas propias del ejercicio jurisdiccional, apareciendo incluso una que, de ordinario, no concurre en otras actuaciones de jurisdicción voluntaria en que intervienen los jueces y magistrados, cual es la contradicción» ${ }^{4}$.

Los procedimientos atribuidos a los Jueces en materia de condición y estado civil de la persona, derecho de familia, restricción de derechos fundamentales y derechos indisponibles, implican reserva judicial y jurisdiccional, es decir, el ciudadano no puede acudir a otro operador jurídico que no sea la Autoridad Judicial.

En relación con este punto cabe señalar, a mi juicio, en relación con la afirmación contenida en la exposición de motivos, apartado tercero, del Proyecto de Ley de 2006, conforme a la cual, «tal y como aparece concebida en la presente ley la jurisdicción voluntaria encuentra su amparo en el artículo 117.4 de la Constitución...», supone a mi juicio una toma de postura doctrinaria en una cuestión sometida a debate en la doctrina europea, así como contrario a la más reciente jurisprudencia del Tribunal Supremo, en cuya sentencia de la Sala Tercera de 22 de mayo del año 2000, dice textualmente: «no se puede afirmar que en la denominada jurisdicción voluntaria, los jueces y tribunales no estén ejerciendo potestades jurisdiccionales, con independencia de que anteriormente que pasó lo mismo, otro proceso contradictorio y en consecuencia, estas potestades quedan amparadas por el artículo 117.3 de la Constitución, las demás funciones -continúa diciendo el Tribunal Supremo- que el artículo 117.4 permite que la ley atribuya a juzgados y tribunales en garantía de cualquier derecho, son aquellas que a diferencia de las denominadas

${ }^{4}$ Vid. especialmente en Ramos Méndez, Derecho Procesal Civil, T. III, cit., pp. 1289 ss; Id. Jurisdicción Voluntaria en negocios de comercio, cit., pp. 23 ss.

Para TARZIA debe considerarse superado el antiguo aforismo iurisdictio in sola notione contentiosa consistit, y es necesario reivindicar algunas garantías fundamentales de la jurisdicción contenciosa también para la jurisdicción voluntaria, así por ejemplo las garantías de la independencia y la tercereidad del juez; para MonTESANO los derechos subjetivos e intereses tutelados por la jurisdicción voluntaria tienen la misma naturaleza que los derechos subjetivos lesionados propios de la jurisdicción contenciosa, y especialmente en los casos de tutela de los derechos de los menores e incapacitados, el procedimiento seguido debe cumplir todas las garantías que informan los procesos contenciosos; Para DENTI, no cabe individualizar una jurisdicción voluntaria con características autónomas respecto de la jurisdicción en general, sino que, por el contrario, en cuanto que se atribuye a órganos judiciales, no se sustrae a las garantías, subjetivas y objetivas, que caracterizan la actividad judicial. Las opiniones de estos autores se encuentran reflejadas en las Atti del XVII Convengo Nazionale del Processo civile en Palermo, celebrado en 1989. 
de jurisdicción voluntaria, no comportan protección jurisdiccional de derechos o intereses legítimos como en los supuestos de participación de los jueces en jurados de administración forzosa o en la administración electoral». Al debate doctrinal sobre la JV se refirió el Fiscal del TS en su intervención, previa a la aprobación de la enmienda que reintrodujo la posibilidad de oposición, en los siguientes términos: «...hay una polémica doctrinal fuerte -sobre- si la JV está incardinada en el 117.3 o en el 117.4. En puridad se podría decir que la contradicción, en cuanto que se va a resolver contradictoriamente, entraría ya en el conflicto y estaríamos más hablando de proceso y más del 117.3...»

Por otra parte, la exclusión de la jurisdicción voluntaria del núcleo esencial indisponible y excluyente de funciones que conforman la potestad jurisdiccional de los jueces previsto en el 117.3 y su inclusión en las funciones de los jueces en garantía de derechos conforme al 117.4, respecto de los que no existe una reserva de jurisdicción, comportaría la posibilidad de traspaso en un futuro de las funciones relativas a menores, incapacitados, discapacitados, desvalidos, derechos indisponibles, supuestos atinentes a intereses públicos, restricción de derechos fundamentales, etc. a otros operadores jurídicos que en un momento determinado fueran considerados más idóneos, lo que, a mi juicio, resulta inasumible en el actual marco constitucional, en atención a la naturaleza de los intereses que están en juego y a la necesidad de que su conocimiento y resolución se atribuya al operador jurídico que goza de un mayor grado independencia e imparcialidad, en su estatuto jurídico, en el marco de la Administración del Estado. Lo que sí cabría afirmar es que las competencias atribuidas a los jueces en el ámbito de la jurisdicción voluntaria, se incluyen, dependiendo de la materia, en los párrafos tercero o cuarto del art. 117.

Parece razonable que algunas de las competencias que actualmente se atribuyen a los jueces, puedan trasvasarse a otros operadores jurídicos en el futuro, pero, a mi juicio, hay determinadas competencias respecto de las que no cabe pensar, con el actual marco constitucional, en una titularidad distinta de la judicial, así por ejemplo respecto a la autorización judicial para esterilizar un incapaz, o para el tratamiento no voluntario de una persona con trastornos psíquicos o para una intromisión legítima en el honor, en la intimidad o en la propia imagen de un menor o incapacitado o para autorizar o aprobar el reconocimiento de la filiación no matrimonial de menores o incapaces o para el nombramiento o remoción de un tutor o curador o para autorizar la venta de un bien del patrimonio 
de una persona con discapacidad o para decidir sobre la custodia de los menores cuando los padres vivan separados o sobre la atribución a uno sólo de los cónyuges de la facultad para realizar actos de administración o disposición de los bienes comunes.

No parece, a mi juicio, razonable que en los señalados y en otros análogos supuestos de JV, quepa cuestionar que el Juez está realizando una actividad de enjuiciamiento propia de la potestad jurisdiccional, consistente en constituir, autorizar, habilitar o complementar la capacidad de una persona, tutelar un interés público o resolver un conflicto cuya relevancia no requiere, a juicio del legislador, que sea dirimido en un proceso contencioso, mediante un procedimiento contradictorio o de ejercicio pacífico del derecho, sustanciado con todas las garantías de la tutela judicial efectiva.

Es decir, hay determinados aspectos que, a mi juicio, necesariamente deben permanecer en el ámbito de la reserva jurisdiccional, y ello, únicamente lo garantiza el 117.3. De modo que el legislador debe ser consciente que si mantiene que la fundamentación de la JV se asienta tan sólo en el párrafo 4 del art. $117 \mathrm{CE}$, cabría que en el futuro se decidiese que alguno o todos los supuestos mencionados se atribuyesen a otros operadores jurídicos, que en el marco de la JV serían Secretarios Judiciales, Notarios o Registradores.

En el sentido expresado, se ha pronunciado, en su preceptivo Dictamen, el Consejo General del Poder Judicial: pag. 23: «sin la nota de la exclusividad del apartado 3 del art. 117, el problema queda reducido a una mera opción del legislador, que podrá sustraer a la intervención judicial lo que constituyen manifestaciones de carácter constitutivo negocial, autorizaciones, aprobaciones u homologaciones...» y Conclusión segunda, pág. 84: «Al considerar que la intervención judicial en los procedimientos de JV no reviste la nota de exclusividad, al tener encaje constitucional en el apdo. 4 del art. 117...». En el texto del Anteproyecto elaborado en la Comisión de Codificación, se afirmaba que las competencias judiciales de JV quedaban amparadas por los párrafos tercero y cuarto del artículo 117 de la Constitución.

En definitiva, parece evidente, a mi juicio, que la fundamentación constitucional de la JV, conforme a la fundamental STS de 22 de mayo de 2000, que se refiere la JV de competencia judicial, debe residenciase o en el párrafo $3 .^{\circ}$ del art. 117 , o en los párrafos $3 .^{\circ}$ y $4 .^{\circ}$ del art. 117 de la CE, o quizás incluso podría resultar más prudente, que no se hiciese referencia a la naturaleza jurídica de la JV, en una sede, como la Exposición de Motivos, que no parece la más apropiada para este menester, con el agravante, a mayor abundamiento, de 
tratarse de una cuestión sometida a debate en la doctrina europea, sin que exista una posición mayoritaria al respecto.

Reparar lesiones de derechos o intereses legítimos o su no reconocimiento y dirimir controversias relevantes, constituye el núcleo esencial de la potestad jurisdiccional, y otorgar tutela judicial efectiva fuera del marco proceso contencioso, en conflictos cuya entidad no requiere un juicio ordinario o en defensa de derechos o intereses legítimos de menores, incapaces, personas con discapacidad, derechos indisponibles o intereses generales, públicos o sociales, mediante una actividad de enjuiciamiento y en aplicación del derecho objetivo, con todos los principios y garantías procesales, forma parte asimismo, a mi juicio, del contenido de facultades atribuidas con carácter exclusivo a Juzgados y Tribunales por el art. 117.3 CE o, en determinados supuestos, en garantía de derechos por el artículo 117.4 CE. En todo caso, la JV judicial, se configura como parte integrante de la idea de Administración de Justicia, considerada como función con un contenido más amplio que el propio del ejercicio de la potestad jurisdiccional.

Cabe afirmar, para concluir este punto, que el procedimiento de JV de competencia judicial, para la protección de derechos e intereses legítimos, requiere una labor de enjuiciamiento por parte del Juez equiparable a la propia de la jurisdicción contenciosa, y una tramitación en la que han de respetarse los principios y garantías inherentes a toda actuación judicial, que debe concluir mediante una resolución judicial de fondo, mediante la que el Juez se pronuncie sobre la cuestión planteada en el curso del expediente, a fin de que el ciudadano obtenga la tutela judicial efectiva en el ejercicio de su derecho o interés legítimo. En definitiva, la pérdida de garantías supone, también en el ámbito de los procedimientos de JV, un menoscabo en la tutela judicial efectiva de los derechos e intereses legítimos de los justiciables. Cabe señalar asimismo que, al igual que sucede en el marco de la jurisdicción contenciosa, el ciudadano puede plantear una cuestión de constitucionalidad sobre el procedimiento de JV en su conjunto o sobre alguno de los preceptos específicos de su normativa.

\section{RACIONALIZAR, DESREGULAR, REDISTRIBUIR Y DESJUDI- CIALIZAR}

El marco constitucional en el que se desenvuelve la tutela judicial, no supone, por otra parte ningún obstáculo en esta materia, para racionalizar el sistema, desregular los procedimientos obsole- 
tos, de nula aplicación práctica o de escasa eficacia, manifestaciones de la actual discordancia entre lo legislado y la actual realidad social, redistribuir entre jueces y secretarios las competencias asignadas al órgano jurisdiccional y desjudicializar aquellos supuestos que por su propia naturaleza jurídica, comprenden a otros profesionales del derecho, en especial notarios y registradores de la propiedad y mercantiles, en atención a su especialización y a la competencia funcional que se les reconoce por el Ordenamiento Jurídico.

Hay que deslindar de entre los actos de JV actualmente judicializados entre aquellos que tienen naturaleza jurisdiccional y aquellos que tienen naturaleza administrativa.

Los actuales actos de J.V. no tienen un carácter unitario sino, por el contrario, una naturaleza heterogenea, fruto del constante incremento de supuestos previstos en la legislación sustantiva en los que se prevé la intervención del juez sin que su actuación se encauce en el marco de un proceso.

La actual JV tiene pues en parte naturaleza jurisdiccional y en parte naturaleza administrativa, según los actos a los que nos refiramos, por lo que no cabe atribuir a la JV naturaleza jurisdiccional o administrativa con carácter global, sino que los actos de JV tienen una naturaleza muy diferente entre sí. Así un pacífico deslinde voluntario entre colindantes, la adveración de un testamento ológrafo, la elevación a escritura pública de un testamento otorgado sin intervención notarial, una subasta judicial no ejecutiva, los expedientes de dominio, la convocatoria judicial de una junta general, el nombramiento de un interventor o liquidador o auditor en los casos previstos legalmente o el examen de la contabilidad de los empresarios, por citar algunos supuestos entre los varios centenares previstos en la legislación, que podrían ser considerados, conforme al art. 117.4 $\mathrm{CE}$, actos atribuidos a los jueces en garantía de derechos, no tienen sin embargo un contenido estrictamente jurisdiccional, sino que más bien parece que nos encontramos ante una actividad de prevalente carácter administrativo, que atribuida en su momento a la autoridad judicial en atención a razones diversas, ha perdido, en el momento actual, su justificación competencial, por lo que sería conveniente su desjudicialización, y consiguiente atribución a otros centros de referencia, operadores jurídicos de la Administración del Estado, que se produciría sin merma de las garantías de la tutela efectiva de los derechos e intereses legítimos de los justiciables.

Por el contrario, la autorización judicial para la esterilización de un discapacitado psíquico, el procedimiento para obtener la 
autorización o aprobación del reconocimiento de filiación extramatrimonial de un menor o un incapacitado o el conflicto derivado del secuestro parental de un menor de edad y el procedimiento para su restitución, son actos de $\mathrm{JV}$, pero de naturaleza muy diferente a la administrativa.

La necesidad de descargar de trabajo a los jueces, concentrar su actuación en tareas jurisdiccionales, redistribuir competencias y racionalizar el sistema en la Administración de Justicia, constituyó, por otra parte, el objeto de una Recomendación del Consejo de Europa, dirigida a los países miembros de fecha 16 de septiembre de 1986. La desjudicialización supondrá la reforma de la correspondiente legislación notarial, registral, funcionarial o la de otros agentes jurídicos, respecto de los que se produzca el traspaso de competencias, dado que parece procedente que en la futura Ley de Jurisdicción Voluntaria se regulen tan sólo las competencias que se mantienen en la órbita judicial y se remita a la legislación notarial y registral la regulación de las materias desjudicializadas.

En la modificación de la Ley Orgánica del Poder Judicial, por Ley de 23-12-2003, artículos 438,3 y 5 y 456,3 y 4, se prevé, por su parte, la competencia de los Secretarios Judiciales, en los actos de jurisdicción voluntaria cuyo conocimiento se les atribuya en las futuras leyes procesales, lo que supone asimismo un reconocimiento expreso de la competencia de estos profesionales del derecho en este ámbito, en la línea con lo previsto en el art. 290 de la LOPJ de 1985, que ya les atribuía las propuestas de autos definitivos en materia de jurisdicción voluntaria.

Se descargaría con todo ello de competencias a los jueces, que se atribuirían a estos funcionarios del derecho, que integran el órgano jurisdiccional, al menos a partir de la LOPJ de 1985, conforme a la opinión de una parte de la doctrina procesalística, cualificados por su preparación jurídica y por su dominio de la técnica procesal, que se encuentran en el momento actual, al decir de la mayoría de los estudiosos que se han pronunciado sobre la cuestión, infrautilizados en el marco de la Administración de Justicia, no obstante, la relevancia de las funciones que se les atribuyen en el marco de la Administración de Justicia: dación de fe, dación de cuenta, ordenación procesal y determinadas competencias en el ámbito de la ejecución.

El procedimiento podría consistir en reconocerles competencia para dictar decretos motivados, con hechos, fundamentos de derecho y fallo, en los asuntos que se les atribuyan, decretos motivados que serían recurribles ante el Juez en primera instancia. La utiliza- 
ción del término decreto supondría, por otra parte, la recuperación de la denominación de la resolución «decretum», con la que el magistrado romano concluía el procedimiento de jurisdicción voluntaria, así como la armonización con la terminología utilizada en la legislación alemana -el Rechtsfleger alemán, equiparable al Secretario Judicial español, concluye el procedimiento de jurisdicción voluntaria, mediante un decreto motivado-, y en la legislación italiana. En los asuntos de jurisdicción voluntaria cuyo conocimiento se mantenga en la exclusiva competencia de los jueces, podría atribuirse al secretario, la tramitación del expediente que debería en todo caso se estudiado y decidido por el juez en auto motivado.

Notarios y Registradores son al propio tiempo, profesionales privados del derecho y órganos de la Administración pública, titulares activos de las funciones públicas que les atribuye el Ordenamiento Jurídico, y responsables de las actuaciones desarrolladas en su ejercicio ante los órganos judiciales.

En relación con la atribución de competencias que, podrían ser transferidas al Notariado ${ }^{5}$, cabe señalar que se hace imprescindible un amplio reconocimiento y atribución al Notariado de competencias desjudicializadas en este sector del Ordenamiento, en atención a la doble condición de los Notarios, de titulares de una función pública al servicio de los intereses generales, y de profesionales privados del derecho, lo que supondrá, por otra parte, la recuperación de un protagonismo en un ámbito, que ya les había sido reconocido por la historia, en atención al desempeño de funciones de autenticación, notificación, documentación, acreditación y ciertos supuestos de homologación y de fe pública extrajudicial, mera presencia o comprobación de hechos y garantía de derechos, en consonancia con la seguridad jurídica preventiva y la finalidad antilitigiosa de la actividad notarial, y que han hecho que el Notario actual, en palabras de Rodríguez Adrados, «no sea un mero fedatario público, sino que realiza un juicio de legalidad del acto en que interviene, cuidando que no sea contrario a las leyes ordinarias y a los presupuestos constitucionales, al propio tiempo que debe realizar un juicio de asesoramiento de los intervinientes».

${ }^{5}$ Vid en este sentido Rodríguez AdRADOs, Naturaleza jurídica del documento auténtico notarial, RDN, XLI-XLII, jul-dcb. 1963, pp. 71-183; Id., Formación del instrumento público, validez, eficacia y libre circulación del negocio jurídico así documentado, incluso en las relaciones de Derecho Internacional Privado, RDN, XCVII-XCVIII, jul-dcb 1977, pp. 109-38; Id., La persistencia histórica de la oralidad en la escritura pública, Madrid, 1996, pp. 177 ss. 
La función notarial se ejerce, por otra parte, de forma independiente e imparcial, sin sometimiento a ordenación jerárquica, y su actuación, incluso en su función de dar fe pública, está sometida al control judicial. No constituye la actividad notarial un servicio público en su concepción administrativa, aunque si supone el ejercicio de un servicio público en cuanto a su función certificante y autorizante, en la medida en que se trata de una delegación parcial de la soberanía del Estado, que controla su recto ejercicio.

Cabe afirmar, en definitiva, en relación con este punto, que el reconocimiento de potestad decisoria a los Secretarios Judiciales en el ámbito de la JV, como reconocidos expertos en derecho procesal, y a su configuración como Cuerpo superior jurídico y único, de carácter nacional, al Servicio de la Administración de Justicia, y la amplia desjudicialización de competencias y su atribución a Notarios y Registradores, como profesionales de acreditada solvencia jurídica y titulares de un servicio público que ejercen por delegación del Estado, supone a una racionalización del sistema, una descarga de trabajo para los Jueces y una lógica ratificación de confianza en la idoneidad de estos operadores jurídicos en el desempeño de esta función, así como en la madurez de la sociedad civil.

No voy a entrar tampoco en este estudio, en el examen detallado de los procedimientos que, a mi juicio, especialmente en el campo del derecho de cosas y en el del tráfico mercantil de sociedades, cabría atribuir en esta materia, al otro relevante Cuerpo de Profesionales del Derecho, el de los Registradores de la Propiedad y Mercantiles, que en cuanto órganos de las Administración, que ejercen una potestad pública, a través del procedimiento registral, podrían asumir todos aquellos procedimientos que incardinados de manera especial, aunque no exclusiva, en el marco de los derechos reales, como la anotación preventiva del crédito refaccionario, o la rectificación de errores en los Asientos del Registro de la Propiedad y en el ámbito del derecho societario, como la convocatoria de juntas generales de sociedades anónimas, de responsabilidad limitada, o asambleas generales de cooperativas en determinados supuestos, o el nombramiento de interventores, liquidadores o auditores en situaciones concretas, tengan clara vocación registral.

Baste decir que, tanto en materia civil como en mercantil determinados procedimientos que se desjudicialicen pueden ser atribuidos con idéntica eficacia tanto a Notarios como a Registradores, que en los supuestos desjudicializados debe suprimirse toda huella procesal y de manifestación de imperio, y que es en sede de disposi- 
ciones finales de la futura Ley Jurisdicción Voluntaria, donde deben incluirse los supuestos que salen de la órbita judicial y en sede de la legislación hipotecaria, notarial y registral, donde debe residenciarse la regulación correspondiente.

\section{ALGUNAS PROPUESTAS A TENER EN CUENTA A TENER EN CUENTA EN RELACIÓN CON EL TEXTO NORMATIVO APRO- BADO EN LA COMISIÓN DE JUSTICIA DEL CONGRESO DE LOS DIPUTADOS EN JUNIO DE 2007}

1) La utilización de las expresiones "administradores del expediente» y «administración y gestión del expediente», contenidas en el Proyecto de JV de 2006, podrían resultar apropiadas en referencia a la función propia de los Notarios y de los Registradores, pero aplicadas a Jueces y Secretarios Judiciales, obedece a una concepción administrativista de la JV que ha quedado por fortuna superada en el texto aprobado en sede de la Comisión de Justicia, por lo que sería deseable su sustitución por las expresiones: «operadores jurídicos competentes» y «tramitación del expediente», en atención a su mayor tecnicismo y a su utilización usual en el lenguaje legislativo, así como en el propio de la doctrina y la jurisprudencia.

En este sentido se ha pronunciado el Consejo General del Poder Judicial en las págs. 34 y 35 de su Informe: «El Anteproyecto denomina "administrador del expediente" a las autoridades o funcionarios a los que la ley, ésta u otra, designe para conocer y resolver los expedientes de JV (art. 2.1), denominación que por ir asociada a la idea de gestión, se considera inadecuada, como se ha indicado, tanto referida a la actividad que se realiza, como, en particular, a la función judicial», y pág. 20: «Lo que el Anteproyecto denomina administradores del expediente -parece que intentando encontrar una denominación genérica a todos ellos- constituye una denominación poco afortunada dado que los procedimientos de JV no son, en puridad, susceptibles de administración sino de tramitación y resolución...».

2) En relación asimismo con la terminología cabe señalar que en materia de JV, en estricta técnica jurídica, la más adecuada, a mi juicio, se corresponde con la utilización de los vocablos acto, procedimiento y expediente. En puridad, previsto en la legislación sustantiva un acto de JV, y atribuida su titularidad a un Juez, Secretario Judicial, Notario o Registrador, se requiere, para la realización del derecho subjetivo o interés legítimo que constituya su objeto, que se incoe un procedimiento a solicitud de persona legitimada o, 
en su caso, de oficio o a instancia del Ministerio Fiscal, si se trata de un procedimiento judicial, en el curso del cual se procederá a la tramitación de un expediente. La utilización abusiva en el Proyecto de Ley, del término expediente, con un carácter totalizador, que abarca de forma indistinta la perspectiva material y la procedimental, constituye un inapropiado reduccionismo lingüístico.

3) La coherencia conceptual exige que desde el propio artículo primero, en el que se atisba una especie de definición legal de JV, se prevea que la discordancia, previa entre los intervinientes o suscitada en la tramitación, se ventile en el propio curso del expediente, salvo que la ley disponga lo contrario. La reflexión expuesta, que pretende ser un ejercicio de realismo y de coherencia entre lo establecido en el art. 1 y lo previsto en el art. 7 del Proyecto de 2006, a propósito de los efectos de la controversia, fue asimismo esgrimida por varios de los portavoces de los grupos parlamentarios, en el debate en la Comisión.

4) En relación con la legitimación, art. 3, habría que prever que el procedimiento pudiese ser incoado de oficio, o a instancia del Ministerio Fiscal, como sucede en múltiples supuestos. En el sentido apuntado se manifiesta el Dictamen del Consejo Fiscal, en el comentario de las Disposiciones Comunes «.......sería conveniente incluir entre los sujetos legitimados al Ministerio Fiscal ya que, en ocasiones, el ordenamiento le encomienda la obligación de promover el expediente como, por ejemplo, en materia de tutela, ausencia o protección del patrimonio de las personas con discapacidad».

En relación con el impulso de oficio por parte del Juez, con la finalidad de «ordenar la práctica de cuantas diligencias y actuaciones se estimen oportunas para asegurarse de la procedencia de lo solicitado o de cualquier extremo útil para la resolución del expediente», cabe subrayar que debiera preverse, con carácter general, en todos los procedimientos con reserva jurisdiccional, en atención a la relevancia de su contenido, así en un procedimiento de declaración de ausencia o fallecimiento o de extracción de órganos y también en aquellos supuestos en los que la resolución del expediente afecte a menores o incapaces, aunque éste no sea de titularidad judicial, por ej. cuando en un expediente de dominio resulten afectados intereses de menores, incapaces o ausentes,

5) En relación con la litispendencia (identidad de objetos) referida a procedimientos sustanciados ante operadores jurídicos de diferente naturaleza, se produce un discutible cambio de regulación en relación con la previsión del Proyecto de otorgar prioridad al 
expediente que se hubiera iniciado con carácter previo, al establecer en el art. 2.2 que: "Cuando se tramiten simultáneamente ante administradores de diferente naturaleza dos o más expedientes con idéntico objeto y sujetos, proseguirá la tramitación del iniciado ante la Administración de Justicia, y se acordará el archivo de los otros expedientes incoados».

6) En materia de días y horas hábiles, se vuelve a la previsión realizada en el art. 9 del texto del Anteproyecto de la Comisión de Codificación, que se atiene a lo previsto al efecto en la jurisdicción contenciosa, si bien, a mi juicio, debiera incorporarse una cláusula de estilo del tipo "salvo que la ley disponga lo contrario», en atención a que el propio texto del Proyecto prevé la habilidad de todos los días y horas en materia de Derecho marítimo, art. 173, así como establece en el art. 13.1 que «Fuera de las horas de audiencia del Juez encargado del Registro Civil, y siempre que la urgencia del asunto lo requiera, le sustituirá el Juez de Instrucción que atienda el servicio de guardia».

Cabría pues en materia de habilidad, volver al régimen general del art. 1812 de la LEC, cuando estén en juego intereses de menores o incapacitados, que no deberían ser objeto de una régimen menos privilegiado que el que se otorga al Derecho Marítimo, o al menos preverse el régimen general de todos los días y horas hábiles en determinados supuestos como: la restitución de menores en los supuestos de sustracción internacional, respecto del que si se dispone la preferencia en la tramitación del procedimiento, art. 68; la autorización para la intromisión legítima en el honor, intimidad o propia imagen del menor o incapacitado, arts. 78 y 79, o los casos de discordancia en el ejercicio de la patria potestad, que pueden afectar por ej. a la potestad de guarda o a la realización o no de una operación o de una transfusión de sangre, al menor o incapaz, arts. 100 ss.

7) En materia de recursos cabe señalar que el reforzamiento del principio de audiencia, de oficio o a instancia de los interesados, implica la posibilidad de que se produzca discordia, discrepancia, contraposición, controversia, contradicción, en suma, entre los intervinientes, y que una vez tramitada y resuelta la contradicción, el recurso contra la resolución, es decir, la doble instancia, parece inherente al procedimiento judicial. La no admisión de los recursos tiene sentido en un procedimiento sin contradicción, de ejercicio pacífico de los derechos, pero supone un menoscabo de la seguridad jurídica y de la tutela judicial efectiva, en un procedimiento en el que 
se admite la posibilidad de controversia y oposición, salvo que la ley disponga lo contrario.

Como fue subrayado por el Decano del Colegio de Abogados de Madrid, Luis Martí, en su intervención «...Un diseño que dice que lo nuclear es el verbal tiene contradicción... y si no hay recursos es algo a corregir. El recurso no es un elemento de dilación, se interpone dentro de plazo o no existe, y lo que tarda es la resolución y no el recurso... Así que si conseguimos que el recurso en esta materia se haga pronto por quien lo tiene que hacer, ya no hay dilación y ahorraría el pleito principal en muchas ocasiones. Además si el recurso se pone quiere decir que la parte que lo interpone está conforme en estar en jurisdicción voluntaria...». La posición favorable del propio Presidente del Colegio Nacional de Secretarios Judiciales, Antonio Dorado, en su intervención parlamentaria y del Secretario judicial Seoane Caharrón en recientes estudios publicados sobre la JV, a que se articule un recurso contra el decreto del Secretario, por el que resuelve en un procedimiento de su competencia, es una buena muestra de la responsabilidad con la que los operadores jurídicos se posicionan ante el texto legal.

En el sentido expresado, y de conformidad con la filosofía de las intervenciones de los comparecientes, que resultaron unánimes en este punto, se ha aprobado la razonable enmienda 109 del Grupo Parlamentario Mixto, que se recoge en el art. 26, conforme al que se reintroduce la previsión de recurso

8) En materia de asistencia técnica y de representación procesal, han sido asimismo unánimes en su filosofía las intervenciones de los comparecientes ante la Comisión de Justicia, en el sentido de resaltar que la intervención de abogados y procuradores siempre han servido para reforzar las garantías del procedimiento, la seguridad jurídica y, en consecuencia, la tutela judicial efectiva.

No resulta justificado, a mi juicio, el radical cambio de criterio legislativo en este punto del Proyecto de JV de 2006, respecto del AJV elaborado en la CGC, consistente en suprimir la intervención preceptiva de abogado. La propensión a equiparar o aproximar, también en este aspecto, procedimientos de JV de distinta naturaleza y atribuidos a distintos titulares de competencia, en aras de la simplificación, de la disminución de formalidades y del coste del expediente, puede suponer, sin embargo, en determinados supuestos, una regresión en el reforzamiento de las garantías de los intervinientes. 
En el A. de 2005, la representación de los interesados en el procedimiento se había regulado con un criterio análogo a la regulación vigente. El interesado debía ser dirigido por abogado, salvo en casos de conciliación, expedientes de cuantía inferior a dos mil cuatrocientos euros, para presentar la solicitud en expedientes que tengan por objeto la adopción de medidas urgentes o que deban instarse en plazo perentorio, expedientes de reconocimiento de filiación extramatrimonial, y para la intervención de los interesados, distintos del solicitante, siempre que no tenga por objeto formular oposición.

Pues bien, el reforzamiento en el PL de los principios de audiencia, dispositivo y aportación de parte, la atenuación del dirigismo judicial, la posibilidad de la práctica de todo tipo de pruebas, lo que redundará en una superación de la verosimilitud a la que se encuentran abocadas, en ocasiones, las tradicionales informaciones, acreditaciones y justificaciones, previstas en la regulación vigente, unido todo ello al reconocimiento expreso de la posibilidad de contradicción y de recursos, en los procedimientos en los que se vean afectados intereses de menores o incapaces, al propio tiempo que supondrá una mejora en las garantías de los intervinientes y en la dialéctica entre los solicitantes, interesados -en especial en aquellos supuestos en que se manifieste un interés contrario o divergente del solicitante- o terceros no interesados, implicará, en determinados procedimientos, una mayor dificultad y complejidad procesal.

Por otra parte, la trascendencia económica, en ocasiones, de los intereses en juego, la necesidad de razonar con criterios de lógica jurídica la utilidad o conveniencia de adoptar una u otra toma de postura, en otras vicisitudes, la proposición o práctica de pruebas, o bien las propias tensiones que generan las controversias en el ejercicio de la patria potestad, las relaciones de menores con el progenitor que no sea titular de la patria potestad o con parientes o allegados, o las divergencias relativas a la administración de los bienes de menores o incapaces o en la administración de bienes gananciales en el seno de la comunidad conyugal etc., parecen razones suficientes para que se reflexione sobre este punto, al efecto de distinguir entre aquellos supuestos en los que la previsible ausencia de dificultad técnica no hace necesaria o conveniente la preceptiva asistencia letrada, y aquellos otros en los que la posibilidad de contradicción o recursos prevista en los propios procedimientos, como sucede en los casos de menores o incapacitados o la existencia de una discrepancia o contradicción atenuada a priori, lo que tiene lugar en los procedimientos en materia de familia, hacen aconsejable la obligada intervención de un abogado. 
Parece aconsejable, en todo caso, el establecimiento de la preceptiva intervención de abogado y la representación procesal por procurador, con carácter general, en todos aquellos procedimientos cuya titularidad se atribuya a los Jueces. En relación con el carácter preceptivo de la intervención de abogado se pronunció la Decana del Colegio de Abogados del Ilustre Colegio de Abogados de Barcelona, en su comparecencia parlamentaria de mayo de 2007, en relación con el Proyecto de JV.

Cabría asimismo plantearse en qué medida resultaría apropiada el carácter preceptivo de la asistencia técnica de abogado y de representación por procurador, en procedimientos tramitados ante los S.J que pueden revestir una especial complejidad, como los expedientes de dominio y de liberación de cargas y gravámenes, la fijación del plazo para el cumplimiento de las obligaciones, el albaceazgo, o la liquidación de averías.

Parece asimismo razonable argumentar que en atención a lo establecido en el art. 22 del Proyecto de JV: «La comparecencia se sustanciará por los trámites del juicio verbal con las siguientes especialidades...", resultase preceptiva la intervención de abogado y procurador, conforme al criterio establecido al efecto para el juicio verbal, en los arts. 23 ss LEC, en materia de primera instancia y apelación.

9) La regulación legal de la cosa juzgada no resulta satisfactoria, dado que la dicción legal puede dar lugar a confusión. En el ámbito de la cosa juzgada formal, parece claro que las resoluciones, dictadas en todo tipo de procesos y procedimientos, que devengan firmes resultan inimpugnables, por lo que producen efectos de cosa juzgada formal, a ello se refiere el art. 207 LEC cuando afirma que «transcurridos los plazos previstos para recurrir una resolución sin haberla impugnado, quedará firme y pasada en autoridad de cosa juzgada...», lo que no obsta, para iniciar un proceso contencioso, con independencia de que hayan variado o no los sujetos, el objeto o las circunstancias o presupuestos propios del procedimiento voluntario precedente y sin que ello deba entenderse, en modo alguno, como una impugnación de la resolución dictada en el marco de la JV.

Sucede, sin embargo, que el art. 25.2, puede generar confusión y cabe interpretar que entra en contradicción con el art. 2.2, al negar efectos de cosa juzgada al auto del Juez y al decreto del Secretario y no distinguir entre cosa juzgada formal, que sí se produce respecto de las resoluciones firmes en el marco de la JV, y cosa juzgada material, que asimismo se produce, a mi juicio, en su efecto negativo, en 
el ámbito de la propia JV, cuando se afirma en el propio art. 2.2 que «Resuelto un expediente de JV por cualquier administrador, no podrá iniciarse otro expediente sobre idéntico objeto y entre los mismos interesados», y no se produce, por el contrario, en su efecto negativo, fuera del ámbito de la propia JV, lo que se prevé en el art. 2.3, al disponerse que: «La resolución de un expediente de JV no impedirá la incoación de un proceso judicial con el mismo objeto».

En definitiva, las resoluciones de JV no comportan efectos de cosa juzgada material fuera del ámbito de la propia JV, pero sí en este ámbito., en sus efectos negativo y positivo. Cabría afirmar, por su parte, en relación con éste último, que cualquier órgano jurisdiccional quedará vinculado en cualquier proceso o procedimiento, y ello encajaría en el denominado efecto positivo de la cosa juzgada material, por el contenido dispositivo de la resolución adoptada en el expediente de JV, siempre que ésta no se cuestione en un proceso ordinario, en cuyo caso el juez no estará vinculado, en medida alguna, por lo decidido en el procedimiento de JV.

Negar efectos de cosa juzgada material a la jurisdicción voluntaria, en su propio marco, introduciría a mi juicio, una peligrosa variable, que sólo generaría inseguridad jurídica a los justiciables y al propio funcionamiento de la Administración de Justicia. Por decirlo con palabras utilizadas por el Fiscal del Tribunal Supremo, Paz Rubio, en su comparecencia ante la Comisión de Justicia, en trámite de asesoramiento del Proyecto de JV: «Estos expedientes producen efecto de cosa juzgada formal porque no se pueden impugnar en el mismo proceso y producen efecto de cosa juzgada material en otro expediente de jurisdicción voluntaria, no en un proceso contencioso posterior pero sí en otro de jurisdicción voluntaria y si se ha resuelto no lo vamos a resolver otra vez, aunque la materia de familia es susceptible de otra modificación».

Mi propuesta sería que el texto del art. 25.2, referido a la cosa juzgada en la JV, quedase redactado del siguiente tenor: «Cuando el operador jurídico competente sea un Juez resolverá el expediente mediante auto, que no tendrá efectos de cosa juzgada material, fuera del ámbito de la jurisdicción voluntaria.

Si el operador jurídico competente es un Secretario Judicial, lo resolverá mediante decreto, que también carecerá de efectos de cosa juzgada material, fuera del ámbito de la jurisdicción voluntaria».

10) En relación con los procedimientos que, a mi juicio, podrían ser objeto de inclusión específica en el texto de la futura Ley de JV, 
aludiré a: a) las propuestas del Cermi, b) A la enmienda 64 de Convergencia i Unió, de inclusión de un nuevo capítulo al Título IV, en materia de Personas, bajo la rúbrica «Del procedimiento para la autorización biológica de la filiación, paternidad o maternidad», y c) A supuestos que incluidos en la LEC, podrían ser trasladados a la futura Ley de JV, en atención a su naturaleza voluntaria.

Desde el sector de la discapacidad, representado por el CERMI, Comité español de representantes de personas con discapacidad, se ha solicitado que: 1) Se articule el procedimiento de JV previsto en el art. 156 del Código Penal, relativo a la autorización judicial de la persona incapaz que adolezca de grave deficiencia psíquica; 2) Se regule la autorización judicial para imponer tratamiento médico forzoso a los enfermos psíquicos y 3) Se valore la conveniencia de que la autorización judicial para el internamiento de personas que padecen trastornos psíquicos, se tramite a través de un procedimiento de JV.

La segunda propuesta del Cermi, que había sido ya asumida en una Proposición de Ley presentada por Convergencia y Unió en 2005 y articulada como procedimiento específico en el Proyecto de Ley, quedó sin efecto al aprobarse una enmienda de supresión del capítulo por el que se había procedido a su regulación. Ahora bien, a mi juicio, la intervención de los representantes del Cermi en la Comisión, así como la posición favorable de varios Portavoces y Comparecientes, con especial referencia por su significación en este Procedimiento, del Fiscal Jefe de la Sala Primera del TS, deberían ser objeto de una nueva valoración.

Las consideraciones, al efecto, atinentes a que se trata de una alternativa, en muchas ocasiones, a una incapacitación, o a un internamiento no voluntario, creo que no han sido suficientemente desvirtuadas por los argumentos en sentido contrario. Se trata de que un acto sanitario como es el tratamiento o el periodo de observación de una persona que no tiene conciencia clara de su enfermedad, pero no hasta el punto de requerir una incapacitación o un internamiento, se articule en un procedimiento con todas las garantías. El problema no está resuelto y los afectados están de acuerdo en la conveniencia y urgencia de la medida. Quizás la ausencia de los preceptivos Dictámenes del Consejo Fiscal y del Consejo General del Poder Judicial, sí deba considerarse una objeción relevante a la articulación del procedimiento en el Texto de referencia.

La tercera propuesta es un claro reflejo del carácter variable y fluido entre ambas esferas de la legislación, manifestado en instituciones como los alimentos provisionales, la incapacitación por 
locura o el internamiento de personas con trastornos psíquicos que se tramitaron por medio de procedimientos de JV antes de pasar a la esfera contenciosa.

En el supuesto del internamiento, el trasvase se materializó con su inclusión en la LEC 2000. Ahora bien, configurado el Procedimiento de JV con todas las garantías propias de la tutela judicial efectiva, establecida su efectiva aplicación a supuestos en que estén en juego intereses de menores e incapaces, hasta el límite incluso de no proceder al trasvase de la esterilización de persona incapacitada al marco de la Jurisdicción contenciosa, con mayor razón debería considerarse de naturaleza voluntaria el internamiento, lo que redundaría por otra parte en una mayor armonización del sistema.

Parece razonable, asimismo, que si se decide, como así parece, mantener la esterilización prevista en el art. 156.2 del C. Penal en el marco de la JV, sería conveniente proceder a la articulación del procedimiento singularizado, en atención a sus específicas particularidades. Es por todo ello que, a mi juicio, sería un acierto que se valorase en sentido positivo su regulación por el Senado.

La propuesta sobre «Investigación biológica de la filiación, paternidad o maternidad» de Convergencia i Unió, está articulada con todas las garantías, pretende llenar un vacío legal sobre una cuestión de creciente trascendencia social, y tiene un entronque claro, entre otros preceptos constitucionales, en el art. 39.2 CE, conforme al cual: «La Ley posibilitará la investigación de la paternidad».

Habría que tener en cuenta, finalmente, a los efectos de su posible trasvase a la Ley de JV, que en la LEC se regulan bajo la denominación de procesos, supuestos sin contradicción de voluntades y de clara naturaleza voluntaria, así sucede por ejemplo: en los denominados procesos matrimoniales de separación o divorcio por mutuo consenso; en las demandas en solicitud de eficacia civil, de las resoluciones de Tribunales eclesiásticos sobre nulidad de matrimonio canónico y de las decisiones pontificias sobre matrimonio rato y no consumado, siempre que no se solicite la adopción o la modificación de las medidas establecidas; o en las demandas en juicio verbal en las que se pretende que el Tribunal ponga en posesión de bienes a quien los hubiere adquirido por herencia si no estuvieren siendo poseídos por nadie a título de dueño o usufructuario. Se contempla en este último supuesto el tradicional interdicto de adquirir la posesión, expresión que ha sido suprimida por la LEC, no obstante, el mantenimiento, en otras ocasiones, de términos, principios, reglas y criterios de perenne valor, acuñados por la tradición jurídica y acogidos 
en las leyes procesales civiles de otros países de nuestra misma área cultural, conforme se afirma, con acierto, en la precisa y afortunada Exposición de Motivos de la Ley Procesal Civil.

Se incluyen de igual modo en la LEC, en atención a motivaciones diversas, instituciones que tienen una naturaleza básicamente de jurisdicción voluntaria, así sucede en relación con las previsiones legislativas referidas a: diligencias preliminares, o a las medidas provisionales previas a las demandas de nulidad, separación o divorcio. En ambos casos, sin embargo, quizás convenga mantener su regulación en sede de la LEC, por razón de sistemática respecto a la regulación de las actuaciones subsiguientes.

\section{EL PROTAGONISMO HISTÓRICO DEL NOTARIADO EN MATERIA DE JURISDICCIÓN VOLUNTARIA}

A lo largo de los siglos IX al XII, en todos los países europeos y singularmente en Inglaterra, Francia, Alemania en Inglaterra, así como en España a partir del siglo XIII, se produce una evolución jurídica consistente en que una parte importante de las actuaciones negociales de JV se realizaban ante los notarios que estaban adscritos a los tribunales tanto laicos, como eclesiásticos. De forma especial, a partir del siglo XII, el conocimiento y resolución de una parte importante de supuestos de JV que se sustanciaban ante los jueces se atribuyó a los Notarios, que se configuran como el órgano por excelencia de la JV en la Europa del Medioevo.

Como ha sido subrayado por Rodriguez Adrados, con anterioridad a la Ley del Notariado de 1862 estaban unidas la fe pública judicial y extrajudicial, y las funciones de documentación propias de los escribanos de los juzgados estaban consideradas como actos de JV. Con la entrada en vigor de la Ley de 1862, se atribuye la fe pública judicial a los Secretarios Judiciales y la fe pública extrajudicial a los Notarios, y se reconoce a estos últimos la función de dar fe de los contratos y demás actos extrajudiciales, pero no se desgajan del ámbito judicial las funciones de documentación, declaración derechos y mera presencia, que desempeñaban los escribanos con anterioridad a la Ley de 1862.

Por otra parte, en el mismo siglo XIX, la Ley Hipotecaria de 1861, configura el actual Registro de la Propiedad y el cuerpo de Registradores de la Propiedad sobre la base de las antiguas contadurías de hipotecas, con la finalidad de proteger a los titulares de derechos 
inscritos, asentar el sistema hipotecario y agilizar el tráfico jurídico inmobiliario, La Ley Orgánica del Poder Judicial de 1870 configura con carácter independiente el cuerpo nacional de Secretarios judiciales, y las dos leyes de enjuiciamiento civil promulgadas, dedican la de 1855, el segundo de sus dos libros a la JV, y la de 1881, el primero de sus tres libros a Disposiciones comunes a la JC y a la JV, el segundo a la JC, y el tercero, todavía vigente, a la JV.

Pues bien, la previsible atribución al Notariado de diversas competencias actualmente de titularidad judicial y, en su caso, la posibilidad que se reconocería a los justiciables para acudir de forma opcional a la actuación notarial, entre uno de los varios operadores jurídicos posibles, en determinadas materias, supondría, en definitiva, no sólo devolver a estos funcionarios públicos y profesionales del derecho, un protagonismo en esta materia que ya les había sido atribuido por la historia, sino también el reconocimiento de unas competencias cuyo ejercicio les corresponden por su propia naturaleza, en atención al desempeño de funciones de autenticación, notificación, documentación y garantía de derechos, lo que hace que el notario actual, en palabras de Rodríguez Adrados, no sea un mero fedatario público, sino que ejerce un oficio público en cuanto a su función certificante y autorizante, al propio tiempo que realiza un juicio de legalidad del acto en que interviene y de asesoramiento de los intervinientes, con sometimiento al control o revisión judicial.

Si regulada la alternatividad, como parece probable, si nos atenemos a las posiciones de los grupos parlamentarios en el debate y aprobación de las enmiendas al respecto en la tramitación del Proyecto de Ley de JV, el justiciable podrá acudir a un Secretario Judicial en atención, a la gratuidad de la Justicia, a la tradicional seguridad que puede proporcionarle al justiciable la actuación ante la Administración de Justicia, o a otras circunstancias, o podrá optar, en los casos previstos, por requerir la prestación del servicio a una Notaría o a un Registro Público, una vez valorado que la satisfacción del arancel fijado por el Gobierno por la prestación del servicio público solicitado, le compensa, por ejemplo, en términos de proximidad, especialidad o celeridad en la resolución del asunto.

A mi juicio, valores como la confianza, la profesionalidad, la cualificación jurídica y la seguridad jurídica son predicables, en los tiempos actuales, al propio tiempo de los Secretarios Judiciales, de los Notarios y de los Registradores.

La seguridad jurídica, proclamada en el art.9.3 CE,, es la suma de legalidad y certeza, según subraya de forma reiterada el Tribunal 
Constitucional. Por su parte, Delgado Echevarría destaca que el art 149.1.8 CE, al atribuir la competencia exclusiva al Estado sobre la ordenación de los instrumentos públicos lleva al plano constitucional la institución del Notariado, a través de su más objetivo producto como es el instrumento público. A su vez, la esencia de la función notarial, y del documento público notarial, por medio del cual el Estado cumple el deber de garantizar la seguridad jurídica, se contiene en los artículos 1, 17bis y 24 de la Ley del Notariado, art. 1 del Reglamento Notarial, art. 1218 del CC, y art 319 LEC $^{6}$.

Conviene asimismo apuntar que la decisión del justiciable de acudir a un operador jurídico distinto del órgano judicial supone, por otra parte, un ahorro de costes para la Administración de Justicia, y que el modelo se seguridad jurídica preventiva o extrajudicial existente, notarial y registral, es una referencia para países emergentes y desarrollados europeos y de otras latitudes ${ }^{7}$.

\section{ESPECIAL REFERENCIA A LAS COMPETENCIAS SUSCEPTI- BLES DE SER ATRIBUIDAS AL NOTARIADO}

En relación con la asignación de competencias específicas relacionadas con el Notariado en el Proyecto de Ley de 2006, aprobado en el Congreso de los Diputados y retirado en el Senado, procederé a reiterar, con alguna mínima adición y revisión, lo que ya he escrito en ésta y otras sedes al respecto, que coincide, en la mayor parte de los casos, con lo aprobado en sede parlamentaria.

Las competencias compartidas podrían conformarse:

A) Entre Secretarios Judiciales y Notarios:

1. Deslinde y amojonamiento

2. Consignación. Sería competencia del Notario declarar, en su caso, bien hecha la consignación, es decir, cumplidos los requisitos de identidad e integridad de la prestación, y sería el Secretario quien podrá declarar cancelada la obligación, conforme a la previsión del Proyecto.

${ }^{6}$ Vid. al respecto en Campo Guerri, La competencia notarial en asuntos no contenciosos. Revista Jurídica del Notariado. N. extraordinario 2010, pp. 517-641.

${ }^{7}$ Sobre actividad y función notarial, en especial, en relación con las personas con discapacidad, vid. en Castro-Girona, La convención de los derechos de las personas con discapacidad y la actuación notarial: el notario «ombudsman» social, Ediar, Buenos Aires 2011, pp. 451- 476. 
3. Declaración de herederos abintestato, de cualquier grado y condición.

Debe, a mi juicio, subrayarse, no obstante, que la disposición de la Ley 10/1992, de30 de abril, de Medidas Urgentes de la Reforma Procesal, que modificó el art. 979 de la LEC de 1881, para atribuir a los Notarios, en sustitución de los Jueces, la mencionada competencia exclusiva, ha resultado un acierto, en atención a casi nula conflictividad producida al respecto desde su entrada en vigor.

4. Presentación, adveración, apertura y protocolización de testamentos cerrados.

5. Presentación, adveración y protocolización de testamentos ológrafos.

6. Presentación, adveración y protocolización de testamentos otorgados en forma oral.

7. Albaceazgo: la no aceptación o renuncia del albacea en el caso de que éste acepte perder lo que le hubiese dejado el testador, conforme al artículo $900 \mathrm{CC}$.

8. Depósitos en materia mercantil y en transporte marítimo.

El Proyecto de JV atribuye asimismo al Notariado, en la Disposición Adicional segunda, ocho procedimientos de derecho hipotecario y dos de derecho mercantil, con competencia compartida con los Secretarios Judiciales, en todos los casos, y con los Registradores en determinados supuestos. En relación con estos procedimientos previstos en la D.A. 2. ${ }^{\text {a }}$, se ha pronunciado José María de Prada, alguna de cuyas reflexiones, que suscribo en todos sus extremos, son las que siguen:

9. Nota marginal de doble inmatriculación. Conforme al artículo 313.2 de la $\mathrm{LH}$, el titular inscrito de cualquier derecho real sobre una finca puede acudir al Juez -con la reforma sería al Secretario Judicial o al Notario- a fin de solicitar que se proceda a la realización de una nota marginal advirtiendo de la posible doble inmatriculación.

10. Procedimiento para completar las circunstancias de los títulos para practicar anotaciones preventivas, conforme al artículo 74 LH. Opina De Prada que si hay acuerdo entre los interesados el Notario podrá ordenar la anotación, pero es dudoso que pueda hacerlo si el otro interesado, como será lo normal, se oponga. 
$11,12,13$. Anotaciones preventivas de legado, de derecho hereditario y de crédito refaccionario: entiende De Prada que si las parte están de acuerdo no parece que haya obstáculos para la intervención notarial, pero si hay controversia o se trata de interesados desconocidos repugna un poco a la esencia de la función notarial que pueda el notario por sí, y aunque sea previo un expediente, ordenar la realización de estas actuaciones.

14. Formación de inventario en garantía de bienes reservables. Observa De Prada que la intervención del notario consistiría en recoger la constancia del carácter reservable de los bienes.

15, 16. En los procedimientos de reconocimiento y depósito cautelar previsto en el art. 367 C.Co y de reconocimiento de efectos mercantiles previstos en los artículos 327, 336, y 366 del C.Co, la actuación notarial encajaría en el acta de presencia para constatar las deficiencias en las mercaderías vendidas o transportadas.

B) Entre Secretarios Judiciales, Notarios y Registradores de la Propiedad o Mercantiles, en determinados expedientes en los que los ciudadanos podrían optar por solicitar la tramitación del expediente ante cualquiera de los tres operadores jurídicos, como podría acordarse en:

1 El expediente de dominio. En relación con la competencia notarial, debería reconocerse la inmatriculación mediante acta de notoriedad y suprimirse la intervención judicial homologadora de la decisión del Notario, en los supuestos de actas notariales de notoriedad para reanudar el tracto sucesivo o registrar los excesos de cabida, por suponer una desnaturalización de la función notarial y una desconfianza hacia su actuación que no parece tener ningún fundamento ni razón de ser. Al expediente de dominio se dedicó una de las partes de una reciente conferencia pronunciada, en este Ilustre Colegio, por el notario José Antonio García Vila.

2. El expediente de liberación de gravámenes.

3. La exhibición de libros de las personas obligadas a llevar la contabilidad.

4. La constitución y régimen interno del sindicato de obligacionistas de personas jurídicas que no sean sociedades anónimas.

5. La nota marginal de doble inmatriculación.

6. El Procedimiento para completar las circunstancias de los títulos para practicar anotaciones preventivas. 
La temática sucesoria en el Anteproyecto de 2005 y en el Proyecto de Ley de 2006, ha sido estudiada con detalle, por José María De Prada y Juan José Marín. Asimismo se han ocupado, entre otros autores, de estudiar en relación con el Notariado, las propuestas de ambos textos legislativos, los notarios Rodriguez Adrados, De Prada, Gómez-Ferrer, García Vila y Campo Guerri.

En relación con la atribución de otras posibles competencias compartidas entre Secretarios Judiciales y Notarios, no previstas en el Proyecto de JV, cabría mencionar, a mi juicio, las siguientes:

1. La presencia y documentación que requiere un matrimonio civil, es una función propia de la labor del Notario y del Secretario Judicial.

2. La separación y divorcio por mutuo consenso, podría asimismo formalizarse ante Notario o Secretario judicial, salvo la aprobación del convenio regulador, en los casos de existencia de menores de edad o incapacitados, que deberá ser aprobado por el Juez.

3. En las uniones de hecho podría regularse la función acreditadora y documentadora del Notario respecto a la existencia real de la convivencia y al tiempo de relación previo a tal acto de constatación.

4. En materia de adopción de mayores de edad y de menores emancipados.

5. La reconciliación que el art. 84 del CC. exige que los cónyuges pongan en conocimiento del Juez, a fin de poner término al procedimiento de separación y dejar sin efecto ulterior lo en él resuelto, podría acreditarse mediante acta notarial.

6. La formalización de inventarios prevista en diversos textos del Código Civil y Ley de Enjuiciamiento Civil y atribuida al Juez, encaja mejor en la función propia de los Notarios y Secretarios Judiciales. Al efecto, en el Anteproyecto de 2005 se había regulado en el artículo 15, ubicado en sede de procedimiento general, la práctica del inventario de bienes.

7. La posesión judicial de bienes a favor de quienes los hubieren adquirido por herencia, si no estuvieren siendo poseídos por nadie a título de dueño o usufructuario -es decir, el tradicional interdicto de adquirir la posesión, conforme a la denominación clásica, sustituida en el art. 250.3 LEC- podría atribuirse al Notariado y a los Secretarios Judiciales, como expediente de JV.

8. La posesión judicial en los casos en que no proceda el interdicto de adquirir, que conforme a la previsión del Proyecto, pasaría 
a la competencia de los Secretarios Judiciales, art. 13.3, es asimismo materia cuyo conocimiento y resolución debería atribuirse, de forma compartida, a Notarios y Secretarios Judiciales.

9. Las subastas judiciales no ejecutivas, atribuidas en el Proyecto de JV en exclusiva a los Secretarios Judiciales, constituyen asimismo, a mi juicio, actuaciones propias de la función notarial, al igual que ya sucede respecto a la realización extrajudicial ejecutiva de bienes de naturaleza diversa, por lo que convendría establecer su carácter de expediente compartido por ambos operadores jurídicos. Se trataría con ello de atenerse a lo previsto en el Anteproyecto de 2005, art. 171.3 que establecía que salvo que la Ley o el tribunal que la hayan ordenado expresamente dispongan lo contrario, los interesados podrán instar la enajenación en subasta notarial.

En relación con este punto, quiero destacar la opinión de Serrano de Nicolás, referente a la dudosa legalidad de la actual regulación del procedimiento de ejecución notarial hipotecaria. Conforme opina este Autor, la futura Ley de JV, es la sede adecuada para articular la regulación de la realización extrajudicial, como venta, o como pacto marciano, al igual que sucede en la legislación francesa, dado que la previsión reglamentaria actual, en puridad, no es una venta, ni judicial ni extrajudicial, y carece de amparo de legal ${ }^{8}$.

10. La protocolización de memorias testamentarias, en los derechos civiles especiales en los que exista como institución propia.

11. La manifestación del heredero, que se hubiese reservado el derecho de deliberar, relativa a la aceptación o el repudio de la herencia, a la que se refiere el art. 1019 CC, deberá realizarse ante el Secretario Judicial, y debería preverse asimismo la competencia notarial.

12. Los testamentos militar y marítimo, arts. 716 a 721 y 722 a 731 CC, o determinadas manifestaciones testamentarias de Derecho Civil de Comunidades Autónomas, en los que no ha intervenido el Notario, requieren la acreditación de su autenticidad y la comprobación del cumplimiento de los requisitos y formalidades legales, lo que constituye una función propia de la actuación notarial. Lo mismo cabría afirmar del testamento realizado en peligro de muerte inminente, en tiempo de epidemia, arts. 700 a 704 CC, o en caso de

${ }^{8}$ Vid. al respecto en Serrano de Nicolás, La ineficient execució hipotecària, n. 2/2011, junio 2011, pp. 3-4, y en La admisión del pacto comisorio como alternativa a la ineficiente subasta hipotecaria (judicial o notarial) El Notario del siglo XXI, N. 21, 2008, pp. 130-135. 
naufragio, art. $731 \mathrm{CC}$, en los que la actuación consistente en autenticar, calificar y documentar las afirmaciones de los testigos, constituyen una función propia de la actuación notarial, como sucede, en general, en una materia, como la testamentaria, esencialmente notarial desde el originario derecho romano, en el que tabeliones eran juristas prácticos especializados en testamentos y contratos.

13. El procedimiento de protesta de mar e incidencias de viaje, en cuanto que se trata de un acto de documentación y presencia, propio de la función notarial.

14. La apertura de escotillas, que cabe documentar mediante un acta de presencia notarial.

A los supuestos mencionados añadiría, después de la lectura del valioso documento de trabajo sobre desjudicialización en el ámbito civil elaborado, en el año 2010, por una Comisión constituida en el seno del Departament de Justicia de la Generalitat de Catalunya ${ }^{9}$, las propuestas que siguen:

- La división de cosa común, por disolución de matrimonio o por herencia, si no hay conflicto entre los interesados, podría realizarse por vía notarial, buscando la autocomposición. Habitualmente, los condóminos no se oponen a la división, sino que sólo quieren asegurar el mejor precio o buscan la adjudicación a uno de los copropietarios. Por otra parte, conforme se subraya en el documento, el Código Civil Catalán establece criterios claros para la división y en muchas ocasiones se produce una reducción importante del valor de los bienes por el ejercicio de la actio communi dividundo en sede judicial y la vía notarial puede asegurar una mejor realización, en la línea seguida por el Código catalán.

En el caso de división de la herencia, prevista en el artículo 782 LEC, si no hay menores o personas incapacitadas, debería preverse, en consecuencia, como suficiente, la vía notarial. En este punto, me parece especialmente oportuno lo escrito por Ángel Serrano en el sentido de que para solucionar los problemas que en ocasiones se producen en las particiones de herencias, una de las posibles vías de solución consistiría en insertar en los testamentos una cláusula en la que se someta a arbitraje del notario la resolución de las posibles discrepancias entre los herederos ${ }^{10}$.

${ }^{9}$ Vid. el Documento en Revista La Notaria, Col-legi de Notaris de Catalunya, n. 2/2010, pp. 30-52.

${ }^{10}$ Serrano de Nicolás, Intervención en el Colegio Notarial de Jalisco en 2004. Podium Notarial, pp. 245-251, www.juridicas.unam.mx 
- El requerimiento de pago, por vía notarial, en el juicio monitorio, conforme a la recomendación de los Presidentes de los Tribunales Superiores de Justicia, en su reunión de noviembre de 2009.

- El expediente de pérdida de letra de cambio, como procedimiento de fijación jurídica propio de la función notarial.

- La declaración notarial de herederos abintestato extensible a los colaterales y a la respectiva Comunidad Autónoma, de no existir parientes dentro del cuarto grado, con asistencia letrada, en su caso, de al menos un mismo abogado para todos los interesados.

- La conclusión del contrato de arrendamiento con abandono del domicilio por parte del arrendatario, no supone ningún conflicto dado que deriva de la renuncia del arrendatario. Este hecho puede comportar la entrega de llaves, la devolución de la fianza o la devolución de la posesión sin intervención judicial, sino por vía notarial, por la que puede acreditarse mediante el correspondiente acta notarial de entrega, exhibición, presencia etc., las correspondientes actuaciones, relacionadas con la finca. Se trataría, en definitiva, de acreditar la entrega de posesión de bienes inmuebles o, en su caso, de bienes muebles, sin que exista contradicción, ni haya sido necesario el uso de la fuerza pública para el desahucio.

En relación, con carácter general, con el procedimiento notarial, cabe señalar que el Decano del Ilustre Colegio de Abogados de Girona, Salvador Capdevila y Bas, en su intervención ante la Comisión de Justicia del Congreso, en mayo de 2007, manifestó, en relación con los recursos, que existe el riesgo de que el procedimiento judicial que se articule en el futuro, -en los casos en los que la competencia se atribuya al Secretario Judicial, se entiende, dado que la competencia judicial es exclusiva- sea más riguroso que el procedimiento notarial o registral previsto para el mismo supuesto.

En opinión de Capdevila y Bas, dado que lo razonable es que, en el procedimiento judicial, el auto del juez sea recurrible en apelación y el decreto del Secretario Judicial lo sea mediante recurso de revisión ante el juez y el auto de éste lo vuelva a ser en apelación, con lo que la doble instancia con lo que ello supone de reforzamiento de las garantías procesales y de la tutela judicial efectiva, quedaría asegurada en sede judicial, habría que plantearse la posibilidad de prever el recurso gubernativo ante la DGRN, en los supuestos de JV desjudicializados, o bien ante los problemas de legalidad que ello pudiese plantear, prever el recurso o la revisión 
de la decisión del Notario o Registrador, de manera directa ante la autoridad judicial.

En la misma línea de reforzamiento de garantías del futuro procedimiento notarial y registral se ha manifestado Ramos Méndez al subrayar que en cualquier hipótesis que se desjudicialice y puedan identificarse intereses contrapuestos, habrá que mantener y respetarlos principios de audiencia y contradicción a fin de facilitar la decisión del operador jurídico competente.

Ante la ausencia de regulación en este punto, opina Campo Güerri que habrá que decidir si el instrumento público a autorizar es una escritura o un acta, si bien el cauce formal más habitual será el acta y dentro de éstas, la de notoriedad, prevista, entre otros, en el artículo 209 del Reglamento Notarial.

Si la oposición se plantea en el expediente tramitado por el notario distingue Campo Güerri, de acuerdo con lo previsto en el artículo $209 \mathrm{RH}$, entre aquellos supuestos en que la contienda tiene carácter jurídico de aquellos otros en que tiene carácter meramente económico y opina que en estos segundos, en la medida que la cuestión pueda resolverse de acuerdo con criterios de equidad, el notario no ha de suspender su actuación, sin perjuicio de que deba fundamentar su decisión y pone como ejemplo el acta notarial instada conforme al derecho catalán, en la que se pretenda la determinación de los parientes más próximos para autorizar la enajenación de un bien perteneciente a un menor, en cuyo caso el notario deberá limitarse a constatar que se dan los presupuestos legales de parentesco y proximidad, así como las correspondientes declaraciones de voluntad de autorización y enajenación, y no estará obligado a suspender la realización del acta por el hecho de que otro pariente del menor se oponga alegando razones económicas, de precio o de oportunidad, con independencia todo ello, añadiría yo, de la posibilidad de instar la revisión judicial de la actuación notarial.

Si se trata de oposición con entidad jurídica distingue el mencionado autor entre que aquella tenga una naturaleza procedimental o sustantiva, en ambos casos el notario habrá de valorar las alegaciones y pruebas solicitadas por las partes o practicadas de oficio, al efecto de decidir si la oposición tiene o no la relevancia suficiente para poner fin a su actuación o continuar con ella, conforme a lo previsto en el art $209 \mathrm{RH} .{ }^{11}$

${ }^{11}$ Vid. al repespecto en Campos Guerri, La competencia notarial en asuntos no contenciosos, cit., pp. 599 ss. 


\section{A MODO DE CONCLUSIÓN}

Es hora ya de que la jurisdicción voluntaria deje de ser un campo de experimentación del legislador. Hay que elaborar una ley lo más completa posible que, escrita con buena técnica jurídica, conforme a las exigencias de la dogmática del derecho procesal:

a) articule un procedimiento general con todas las garantías inherentes a cualquier actuación judicial, entre las que cabe destacar, que la oposición no impida la continuación en la tramitación del expediente, salvo que la ley disponga lo contrario, la posibilidad de recurrir en apelación el auto definitivo del Juez o en revisión el decreto del Secretario Judicial y el mantenimiento, salvo las excepciones previstas en la Ley, del carácter preceptivo de la asistencia técnica de abogado y la representación del procurador, junto con la previsión del beneficio de justicia gratuita, frente a la actual identificación de la institución con supresión o disminución de garantías, plazos o formalidades, en detrimento de la tutela judicial efectiva.

b) suprima los procedimentos obsoletos, reforme los todavía útiles, y traslade de otros textos legales los que tienen naturaleza voluntaria y se considere que deban ser incorporados al nuevo texto legislativo.

c) desjudicialice competencias, en aras de la racionalización del sistema, y las atribuya a otros profesionales del derecho, Notarios y Registradores, de forma especial, las que razonablemente les correspondan por su propia naturaleza, especialización y posición funcional en el marco del Ordenamiento Jurídico.

d) redistribuya competencias en el seno del órgano judicial entre Jueces y Secretarios Judiciales, y

e) reconozca al justiciable la posibilidad de optar, en determinados procedimientos respecto de los que no exista reserva judicial, entre acudir a un Secretario Judicial o a un operador jurídico extrajudicial, Notario o Registrador de la Propiedad o Mercantil, lo que constituye una manifestación de confianza en la madurez de la sociedad civil.

f) constituya el punto de partida para la elaboración de una dogmática y una teoría general de la jurisdicción voluntaria, con principios informadores y reglas de procedimiento, que la incardine de forma definitiva en el campo de la ciencia procesal y la aleje de la mera técnica procedimental. 
Estamos ante la oportunidad de modernizar la Justicia en esta materia y de hacerlo con voluntad de permanencia en el tiempo, desde una posición de progreso y con el mayor consenso político posible, en una esfera del Ordenamiento de marcado carácter técnico-jurídico, caracterizada por la estrecha conexión con la vida diaria de los ciudadanos y por la relevante trascendencia práctica de muchas de sus manifestaciones, en el que el debate no debe ser ideológico, sino en todo caso de concepción o filosofía de la jurisdicción voluntaria. Se trata, en definitiva, de dar respuesta, también en esta parcela del Ordenamiento Jurídico, al desafío de una Justicia más moderna, racional y eficaz.

Antonio Fernández de Buján, Catedrático de la Universidad Autónoma de Madrid 